\title{
The Impact of SST-Forced and Unforced Teleconnections on 2015/16 EI Niño Winter Precipitation over the Western United States
}

\author{
YOUNG-KWON LIM \\ Global Modeling and Assimilation Office, NASA Goddard Space Flight Center, and Goddard Earth Sciences \\ Technology and Research, I.M. Systems Group, Greenbelt, Maryland \\ SIEGFRIED D. SCHUBERT \\ Global Modeling and Assimilation Office, NASA Goddard Space Flight Center, Greenbelt, and Science \\ Systems and Applications Inc., Lanham, Maryland \\ YeHUI CHANG \\ Global Modeling and Assimilation Office, NASA Goddard Space Flight Center, Greenbelt, and Goddard Earth \\ Sciences Technology and Research, Morgan State University, Baltimore, Maryland \\ ANDrea M. MOLOD AND STEVEN PAWSON \\ Global Modeling and Assimilation Office, NASA Goddard Space Flight Center, Greenbelt, Maryland
}

(Manuscript received 3 April 2017, in final form 16 April 2018)

\begin{abstract}
The factors impacting western U.S. winter precipitation during the 2015/16 El Niño are investigated using the Modern-Era Retrospective Analysis for Research and Applications, version 2 (MERRA-2), data, and simulations with the Goddard Earth Observing System, version 5 (GEOS-5), atmospheric general circulation model forced with specified sea surface temperatures (SSTs). Results reveal that the simulated response to the tropical Pacific SST associated with the 2015/16 El Niño was to produce wetter than normal conditions over much of the North American west coast including California-a result at odds with the negative precipitation anomalies observed over much of the southwestern United States. It is shown that two factors acted to partly counter the canonical ENSO response in that region. First, a potentially predictable but modest response to the unusually strong and persistent warm SST in the northeastern Pacific decreased precipitation in the southwestern United States by increasing sea level pressure, driving anticyclonic circulation and atmospheric descent, and reducing moisture transport into that region. Second, large-scale unforced (by SST) components of atmospheric variability (consisting of the leading modes of unpredictable intraensemble variability) resembling the positive phase of the North Atlantic Oscillation and Arctic Oscillation are found to be an important contributor to the drying over the western United States. While a statistical reconstruction of the precipitation from our simulations that account for internal atmospheric variability does much to close the gap between the ensemble-mean and observed precipitation in the southwestern United States, some differences remain, indicating that model error is also playing a role.
\end{abstract}

\section{Introduction}

The El Niño event that occurred in 2015/16 ranks as one of the strongest events in the last six decades (Bell et al. 2016; Huang et al. 2016; L'Heureux et al. 2017; Lim et al. 2017). Strong El Niño events have historically

Corresponding author: Young-Kwon Lim, young-kwon.lim@ nasa.gov produced wet conditions over the southwestern United States (Ropelewski and Halpert 1986; Cayan et al. 1999; Larkin and Harrison 2005; Lau et al. 2008; Hoell et al. 2016; Jong et al. 2016), and as such the 2015/16 event was expected to ameliorate the long-lasting drought over California. That fact that this did not occur came as a surprise to much of the climate community and ran counter to the numerous predictions for ENSO SSTforced wet conditions over the southwestern United 
States that winter (e.g., http://www.cpc.ncep.noaa.gov/ products/NMME/archive/2015110800/current/usprate_ Seas1.html; see also https://wrcc.dri.edu/Climate/Docs/ WRCC_ElNino_092015.pdf). The focus of this paper is to examine the reasons why the 2015/16 strong El Niño apparently failed to produce the expected wet conditions over the U.S. Southwest (especially in Southern California and Arizona).

We consider a number of factors that might have contributed to the observed negative precipitation anomalies over the southwestern United States during the winter of 2015/16. These include a possible change in the character of ENSO, a response to the SST associated with a vast pool of warm water off the North American west coast, and unforced internal atmospheric variability.

There is now considerable evidence that the character of ENSO is not constant but in fact has different "flavors" (Ashok et al. 2007; Kao and Yu 2009; Kug et al. 2009): an eastern Pacific (EP) El Niño and a central Pacific (CP) El Niño, differentiated by the location of the maximum warming region over the equatorial $\mathrm{Pa}$ cific, in the Niño-3 $\left(150^{\circ}-90^{\circ} \mathrm{W}\right)$ or Niño-3.4 region $\left(170^{\circ}-120^{\circ} \mathrm{W}\right)$ during EP El Niño events and the Niño-4 region $\left(160^{\circ} \mathrm{E}-150^{\circ} \mathrm{W}\right)$ during $\mathrm{CP}$ El Niño events. In addition, several studies suggest that the frequency of extreme El Niño events is projected to increase under global warming (e.g., Cai et al. 2014), along with an increase in the ratio of CP-to-EP El Niño events (Yeh et al. 2009; Kim and Yu 2012). While some ENSO events are clearly distinguished as either $\mathrm{CP}$ or EP, there are also many events that commingle the types (Capotondi et al. 2015). For example, the 2015/16 El Niño was characterized by the maximum SST anomaly occurring in the Niño-3.4 region (Bell et al. 2016; L'Heureux et al. 2017). The warming, however, extended to west of the date line, while the SST anomalies in the far EP were rather weak. Lim et al. (2017) concluded that the 2015/16 El Niño event had characteristics of both central and eastern equatorial Pacific warming, whereas the 1997/98 and 1982/83 events were strong EP-type El Niño events. There is evidence that such a difference in the SST anomalies could have led to a different response over North America including the western United States (e.g., Washington, Oregon, California, and Arizona) (Hoerling et al. 1997; Trenberth et al. 1998; Barsugli and Sardeshmukh 2002; Yu et al. 2012; Yu and Zou 2013). For example, earlier studies suggested that both the Pacific-North American (PNA) and the tropical Northern Hemisphere (TNH) (Mo and Livezey 1986; Barnston et al. 1991) teleconnection patterns spanning the extratropical Pacific and North America are sensitive to the type of El Niño (Mo 2010; Yu et al. 2012): the positive phase of the PNA pattern tends to be more active when El Niño has CP warming, whereas the negative phase of the TNH pattern is more active in events with primarily EP warming. It is noteworthy that the PNA pattern response appears to also be influenced by the phase of the quasi-biennial oscillation, so it may not always be in a strong positive phase during El Niño events (Garfinkel and Hartmann 2008).

The role of a so-called warm water blob (WWB), a vast pool of warm water off the North American coast, has received considerable attention since it was first observed in 2013 (Bond et al. 2015). Development of the WWB in 2013 was not related to other recognized patterns of ocean variability such as those associated with ENSO or the Pacific decadal oscillation (PDO) (Mantua et al. 1997; Di Lorenzo and Mantua 2016). There is evidence that the WWB negatively affected marine life over the Pacific coast. It was reported that marine ecosystems suffered and the food web was disrupted by the abnormally warm, less nutrient-rich Pacific Ocean water (e.g., Opar 2015; Whitney 2015). As to the impact on weather and climate, earlier studies concluded that the hot and dry conditions over the western United States might be tied to the WWB. For example, Bond et al. (2015) found a lagged relationship between the WWB and surface air temperature in Washington State. $\mathrm{Hu}$ et al. (2017) suggested that the persistent atmospheric anomalies in the northeastern Pacific in 2015 could be explained by both the impact of the WWB and the strong 2015/16 El Niño. The WWB also appears to be associated with radiative fluxes and precipitation/evaporation above the northeastern Pacific Ocean (Blunden and Arndt 2016). However, the extent to which the WWB is responsible for the western U.S. drought and especially the unexpected dry conditions over California during 2015 is unclear.

Internal modes of atmospheric variability (unforced by SST) are known to impact climate variability over the United States (Hoerling and Kumar 1997; Thompson and Wallace 1998; Kamae et al. 2017), including southwestern U.S. precipitation (Seager et al. 2015). There is in particular evidence that the North Atlantic Oscillation (NAO) and the Arctic Oscillation (AO), while having substantial impact on variability over the eastern United States, also play a role in modulating the southwestern U.S. climate (McAfee and Russell 2008; Myoung et al. 2015). The PNA pattern is another mode of variability that is understood to be primarily internal to the atmosphere. For example, Simmons et al. (1983), Straus and Shukla (2002), Yu (2007), and Schubert and Lim (2013) found that the PNA pattern can be generated with little direct forcing from ENSO, although, as mentioned earlier, there is evidence that ENSO can act to modulate the PNA pattern. Regarding the ENSO 
impact on the PNA pattern, the positive phase of the PNA pattern tends to be more active during $\mathrm{CP}$ warming events. However, the main geopotential height and cyclonic circulation anomalies over the extratropical Pacific associated with the positive phase of the PNA pattern tend to be located far from the western U.S. coast. Thus, the moist southerly (and southwesterly) flow in the eastern side of this cyclonic circulation anomaly does not efficiently supply moisture to the California region, and it is not very influential in driving wet conditions over the southwestern United States during El Niño (Leathers et al. 1991; Woodhouse 2003; Ge et al. 2009; Yu et al. 2012).

We address the extent to which the above factors impacted southwestern U.S. winter precipitation during the 2015/16 El Niño using the Modern-Era Retrospective Analysis for Research and Applications, version 2 (MERRA-2) (Gelaro et al. 2017), data, and various simulations with the NASA Goddard Earth Observing System, version 5 (GEOS-5), atmospheric GCM (AGCM) (Molod et al. 2015) with specified SST. The paper is organized as follows. Section 2 introduces the reanalysis data, models, and experimental design. The North American winter climate during the 2015/16 El Niño event is described and compared with those of other past strong El Niño events (1982/83 and 1997/98) in section 3. Section 4 describes the results obtained from the AGCM simulations, including an assessment of the role of the WWB during the 2015/16 ENSO event. The predictability and contribution of unforced atmospheric variability to the southwestern U.S. precipitation is addressed in section 5. Section 6 discusses the results in previous sections and the sensitivity of the precipitation response to the character of equatorial Pacific SST and addresses some remaining issues.

\section{Data and model experiments}

\section{a. Reanalysis and observations}

The primary atmospheric reanalysis data for this study are those from MERRA-2 (Gelaro et al. 2017). MERRA-2, developed by the NASA Goddard Space Flight Center (GSFC) Global Modeling and Assimilation Office (GMAO), is an updated version of MERRA (Rienecker et al. 2011) with an improvement of the model's physical parameterizations including moist processes ${ }^{1}$ turbulence, land and ocean surface, and gravity

\footnotetext{
${ }^{1}$ The changes include an increased reevaporation of frozen precipitation and cloud condensate, resolution-aware parameters, and a Tokioka-type trigger on deep convection as part of the relaxed Arakawa-Schubert convective scheme (Moorthi and Suarez 1992).
}

wave drag (Bosilovich et al. 2015; Molod et al. 2015; Gelaro et al. 2017). The key variables used here consist of 2-m air temperature, precipitation, sea level pressure, $850-\mathrm{mb}$ wind and specific humidity, and geopotential height at 500 and $250 \mathrm{mb}(1 \mathrm{mb}=1 \mathrm{hPa})(\mathrm{GMAO} 2015 \mathrm{a}, \mathrm{b}, \mathrm{c})$. The horizontal resolution of the MERRA- 2 data is $0.625^{\circ}$ longitude $\times 0.5^{\circ}$ latitude. The observed SSTs used for analysis and AGCM experiments consist of the NOAA Optimal Interpolation Sea Surface Temperature (OISST) data (Reynolds et al. 2007) and Operational Sea Surface Temperature and Sea Ice Analysis (OSTIA) data (Donlon et al. 2011).

\section{b. NASA GEOS-5 model}

We use the NASA GEOS-5 AGCM for the model experiments ${ }^{2}$ performed for this study. The model is run with 72 hybrid sigma-pressure vertical levels, extending to $0.01 \mathrm{hPa}$, and $1.25^{\circ}$ latitude-longitude horizontal grid spacing. The convection scheme is a modified version of the relaxed Arakawa-Schubert (RAS) scheme of Moorthi and Suarez (1992). It includes a stochastic Tokioka trigger function (Tokioka et al. 1988; Bacmeister and Stephens 2011) that governs the lower limits on the allowable entrainment plumes (Bacmeister and Stephens 2011; Lim et al. 2015; Molod et al. 2015). The model has the option for a standard single-moment microphysics (Bacmeister et al. 2006) or a two-moment cloud microphysics (Barahona et al. 2014) embedded within the RAS convective parameterization, and the simulations described here used the single-moment option. The model also includes the catchment land surface model developed by Koster et al. (2000). Further details about the GEOS-5 AGCM can be found in Rienecker et al. (2008) and Molod et al. (2015).

\section{c. Experimental design}

We carried out a number of AGCM experiments distinguished by having different prescribed SST boundary conditions. The full list of experiments is presented in Table 1. Our control experiment (CTL) has the observed SST everywhere, so it includes the impact of both the tropical 2015/16 El Niño SST and those associated with the WWB. Another experiment, NW (here NW stands for no WWB), is forced by the same SST as CTL everywhere except over the northeastern Pacific region, where the SSTs associated with the WWB are removed. To do that, we compute the component of the SST in that region forced by the 2015/16 El Niño itself. To estimate that

\footnotetext{
${ }^{2}$ The internal designation of the AGCM version used here is GEOS-5 Heracles 4.3.
} 
TABLE 1 . Summary of the main and the auxiliary experiments carried out in this study.

\begin{tabular}{|c|c|c|c|c|}
\hline & Expt name & Prescribed SST & Information & Members \\
\hline \multirow[t]{3}{*}{ Main expt } & CTL & Obs 2015/16 SST everywhere. & El Niño and WWB effect. & 50 \\
\hline & NW & $\begin{array}{l}\text { Same SST as expt CTL, but for the } 2015 / 16 \text { El Niño } \\
\text { associated SST over the northeastern Pacific. }\end{array}$ & El Niño, but no WWB effect. & 50 \\
\hline & CLIM & SST is climatological (1980-2015) everywhere. & $\begin{array}{l}\text { No El Niño. } \\
\text { No WWB effect. }\end{array}$ & 20 \\
\hline \multirow[t]{5}{*}{$\begin{array}{l}\text { Auxiliary } \\
\text { expt }\end{array}$} & SC & A: Obs $2015 / 16$ SST over the entire equatorial Pacific. & $\begin{array}{l}\text { 2015/16 El Niño effect from } \\
\text { both EP and CP warming. }\end{array}$ & 10 \\
\hline & & $\begin{array}{l}\text { B: Obs } 2015 / 16 \text { SST over the central equatorial } \\
\text { Pacific }\left(160^{\circ} \mathrm{E}-150^{\circ} \mathrm{W}, \text { Niño- } 4 \text { region }\right) \text { only. }\end{array}$ & $\begin{array}{l}\text { CP warming effect in } 2015 / 16 \\
\text { El Niño. }\end{array}$ & 10 \\
\hline & & $\begin{array}{l}\text { C: SST composite of the recent CP El Niño events } \\
\text { over the central equatorial Pacific only. }\end{array}$ & $\begin{array}{l}\mathrm{CP} \text { warming effect in the } \mathrm{CP} \\
\text { El Niño events. }\end{array}$ & 10 \\
\hline & SS & A: Obs 1997/98 SST everywhere. & 1997/98 El Niño. & 10 \\
\hline & & B: Historic mean El Niño SST everywhere. & $\begin{array}{l}\text { El Niño effect from historic } \\
\text { mean El Niño SST. }\end{array}$ & 10 \\
\hline
\end{tabular}

contribution, we regress the observed SST anomaly for the period 1951-2014 (with the global mean trend removed) onto the Niño-3.4 index, and then scale the regressed SST anomalies based on the magnitude of the 2015/16 Niño-3.4 index. This procedure for estimating the SST associated with the 2015/16 El Niño is conducted separately for each month from June through February, which covers the El Niño growth to maturity. These estimates, which now include only the SST anomalies associated with the 2015/16 El Niño, are then prescribed over the northeastern Pacific in experiment NW. Figure 1 outlines the SST domains for each experiment. The ensemble members are distinguished by having different atmospheric and land initial conditions taken from MERRA-2 during the 50-day period 1 June through 20 July 2015. We also conducted climatological SSTforced runs (CLIM: no El Niño and the WWB effect) to compare them with those from experiments NW and CTL. For these runs, the SSTs are prescribed to be climatological (SSTs are averaged over the period 19802015) everywhere with the atmosphere/land initial conditions taken from MERRA-2 for the year 2015/16. Thus, the only difference between the runs for experiments NW, CTL, and CLIM is the SST distribution prescribed in the model. The integrations are approximately nine months in length, ending on 1 March of the following year.

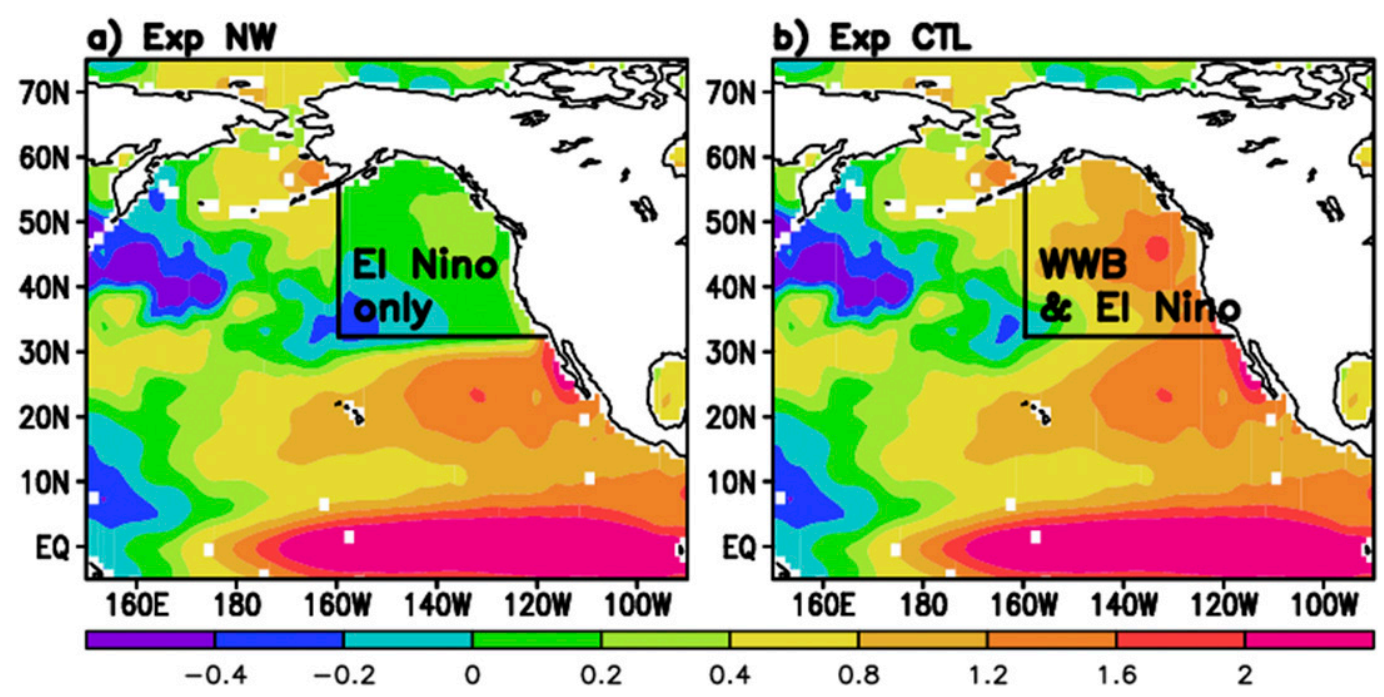

FIG. 1. Pacific domain depicting how the SST is prescribed for (a) expt NW and (b) CTL, respectively. CTL has the observed SST prescribed globally, while expt NW differs only from CTL in that the SSTs in the region of the WWB are set to only the 2015/16 El Niño-associated SST to remove the warmer SSTs associated with the northeastern Pacific WWB. Shading shows the smoothed SST anomaly distribution (K) averaged over the simulation period from July 2015 through February 2016. See text for details. 

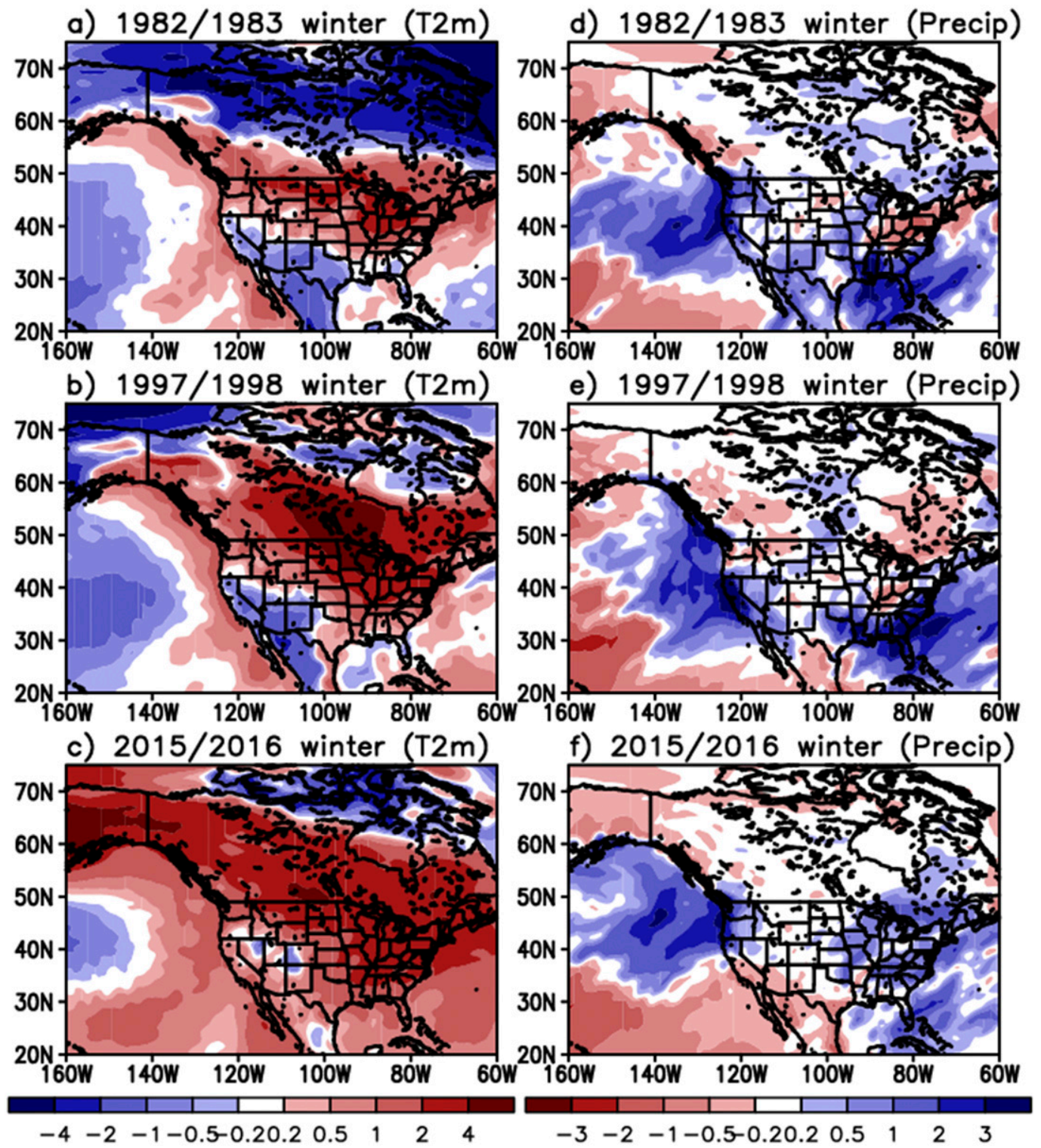

FIG. 2. Distributions of the (a)-(c) MERRA-2 2-m air temperature anomalies (K) and (d)-(f) precipitation anomalies $\left(\mathrm{mm} \mathrm{day}^{-1}\right.$ ) for three strongest El Niño winters (DJF), for (top) 1982/83, (middle) 1997/98, and (bottom) 2015/16.

While the primary focus in carrying out the above experiments was on understanding the role of the WWB and internal atmospheric variability in impacting the El Niño response, we have carried out a number of additional sensitivity experiments to help clarify and confirm aspects of those runs. In particular, auxiliary experiments were done that examine the sensitivity of the response to the character of equatorial Pacific SST and to the overall strength of El Niño. To address the sensitivity to the character of the equatorial SST, we carried out three simulations with 1) observed 2015/16 SST prescribed over the entire equatorial Pacific (designated A),
2) observed 2015/16 SST over the central equatorial Pacific only $\left(160^{\circ} \mathrm{E}-150^{\circ} \mathrm{W}\right.$; Niño-4 region) (designated $\left.\mathrm{B}\right)$, and 3) the same as in the B simulation but for an SST composite of the recent CP El Niños (1987/88, 1991/92, 1994/95, 2002/03, 2004/05, and 2009/10) over the central equatorial Pacific (designated C). In each of those sets of runs, the SSTs are prescribed to climatology everywhere else. We will refer to this set of runs as experiment SC (i.e., sensitivity to character). Another set of runs examines the sensitivity of the GEOS-5 AGCM response to the strength of El Niño. Here, two experiments were conducted that had 1) the observed 1997/98 SST prescribed 
a) SLP, DJF2015/2016

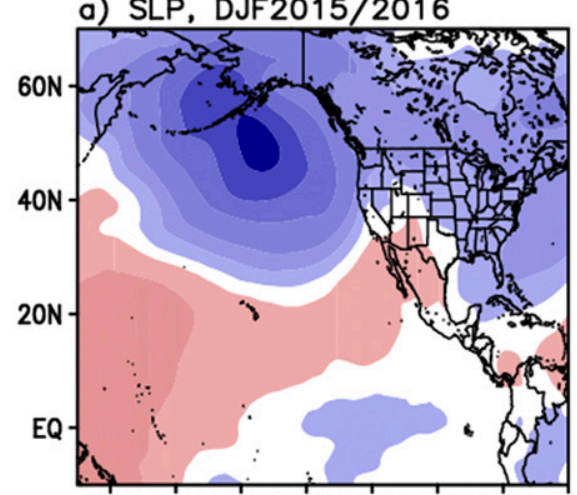

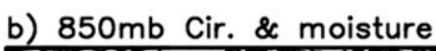

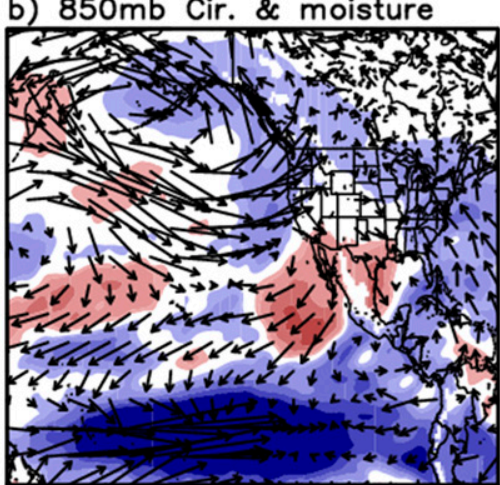

c) 2250 , DJF2015/2016

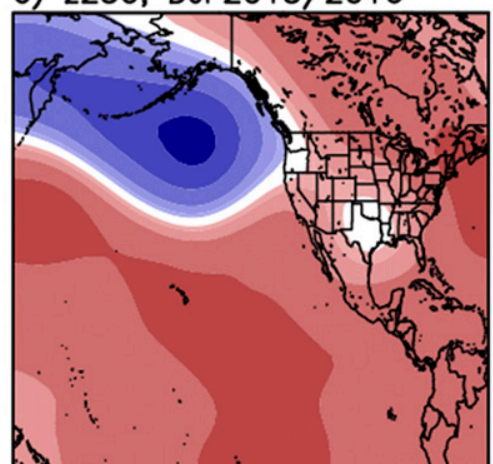

160E 180 160W 140W120W 100W 80W 60W 160E 180 160W140W 120W100W 80W 60W 160E 180 160W140W120W100W 80W 60W

$-16-12-8-4-2-0.50 .524 \quad 8 \quad 1216$

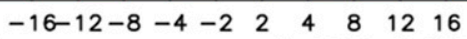
$-12080-40-20-1010204080120$

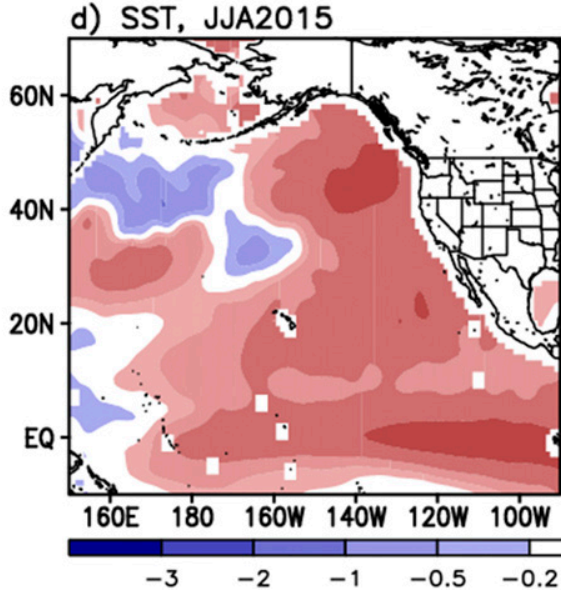
e) SST, DJF2015/2016

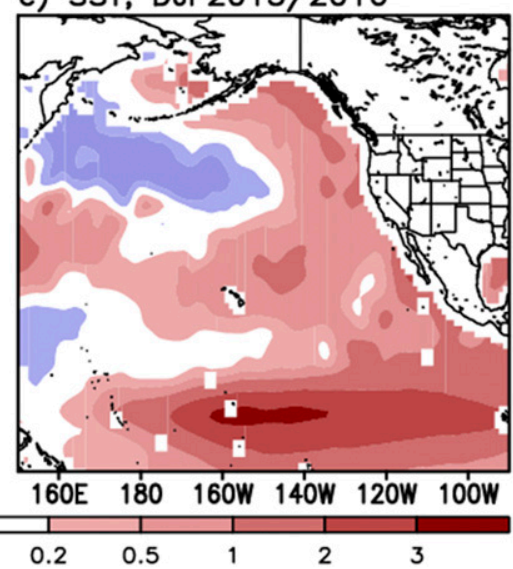

FIG. 3. Anomalous distribution of (a) SLP (mb), (b) 850-mb specific humidity $\left(10^{-1} \mathrm{~g} \mathrm{~kg}^{-1}\right.$; shaded) and horizontal wind (m s${ }^{-1}$; vectors), and (c) z250 (m) from the MERRA-2 for DJF 2015/16. The observed SST anomalies (K) in (d) JJA 2015 and (e) DJF $2015 / 16$.

globally (another very strong El Niño; designated B) and 2) the historic mean El Niño SST prescribed globally (the average of 1982/83, 1986/87, 1987/88, 1991/92, 1994/95, 1997/ 98, 2002/03, 2004/05, 2006/07, and 2009/10; designated B). We shall refer to this set of runs as experiment SS (i.e., sensitivity to strength).

\section{Observed conditions during the $2015 / 16$ winter}

We first examine the observed atmospheric anomalies during the 2015/16 El Niño winter. Previous studies have shown that the United States tends to have cold and wet conditions over the southeastern, eastern, and southwestern United States, and warm winters over parts of the northern United States during El Niño events (Ropelewski and Halpert 1986; Larkin and Harrison 2005; Seager et al. 2005; Lau et al. 2008). Figures 2a, 2b, $2 \mathrm{~d}$, and $2 \mathrm{e}$ show, for example, that during the 1982/83 and 1997/98 El Niño events the western and southeastern (Florida) United States experienced cold and wet winters, which is consistent with the canonical response to strong El Niño events. In contrast, the winter anomalies in 2015/16 are quite different (Figs. 2c,f), showing warmer and drier conditions over the U. S. Southwest.

Figure 3 provides some insight into the nature of the precipitation and temperature anomalies that occurred during the 2015/16 winter. Figure 3a shows that the winter was characterized by a strong negative SLP anomaly over the northeastern Pacific, with weak positive SLP anomalies across the southwestern United States and Mexico. Interestingly, this negative SLP anomaly is located somewhat to the northwest of that observed during previous strong El Niño years (figure not shown). We will come back to this point later in our discussion of the role of the WWB in section 4. The lower-tropospheric circulation and humidity in Fig. $3 \mathrm{~b}$ show a large region of positive humidity anomalies over the tropical Pacific, associated with El Niño. There is also a strong cyclonic circulation anomaly combined with the positive humidity anomalies along the western 
a) z250 (DJF2015/2016)

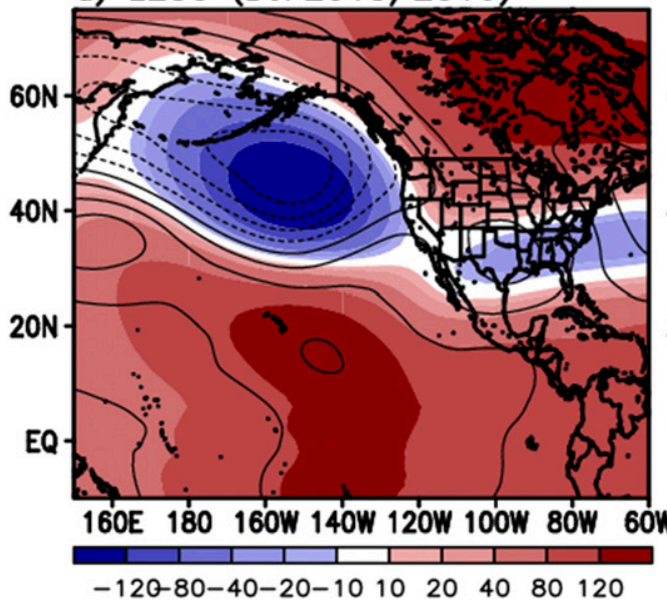

b) Precipitation (DJF2015/2016)

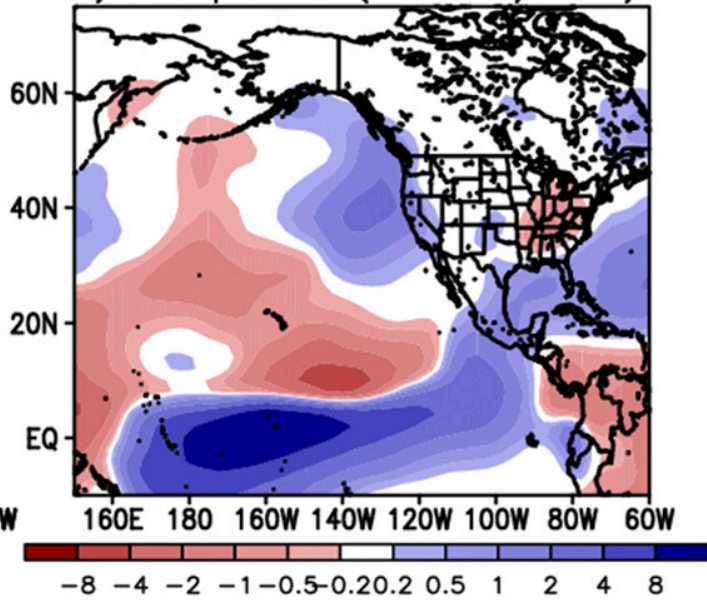

FIG. 4. (a) The $\mathrm{z} 250$ anomalies (m; shaded) and (b) precipitation anomalies $\left(\mathrm{mm} \mathrm{day}^{-1}\right.$ ) for DJF $2015 / 16$ produced by the GEOS-5 AGCM forced with observed SST prescribed globally (CTL - CLIM). Contours in (a) denote the $\mathrm{z} 250(\mathrm{~m})$ anomalies from MERRA-2. Contour interval is $30 \mathrm{~m}$.

coast of North America. In contrast, the southwestern United States and Mexico are characterized by negative moisture anomalies, along with weak offshore flow. Consistent with the lower tropospheric anomalies, the upper-tropospheric geopotential height anomaly distribution at $250 \mathrm{mb}(\mathrm{z} 250)$ consists of a large negative anomaly over the northeastern Pacific with a positive anomaly extending over the southwestern United States (Fig. 3c). The above atmospheric circulation and pressure anomaly patterns over the southwestern United States are unusual for a strong El Niño event and require explanation if we are to understand the nature of the tendency for drying over that region, along with the wetter than normal conditions over the northwestern United States (Fig. 2f).

Figures $3 \mathrm{~d}$ and $3 \mathrm{e}$ show that there was some evolution of the Pacific SST during the time period of the AGCM simulations. In particular, the WWB SST showed some weakening as El Niño reached maturity in the winter of 2015/16, although the positive SST anomalies are still dominant in the northeastern Pacific with the maximum greater than $1 \mathrm{~K}$. The fact that the largest warm anomalies are observed close to the North American west coast during the winter suggests that the impact of the maturing El Niño (by forcing the negative SLP anomaly in the northeastern Pacific discussed above) was to reduce the strength of the warming in the central North Pacific (Di Lorenzo and Mantua 2016).

We next examine whether SST anomalies other than those in the tropical Pacific contributed to the unexpected seasonal precipitation anomalies over the western United States during the winter 2015/16. We focus in particular on isolating the role of the SST in the northeastern Pacific (the WWB) and how that compares with the forcing from SST elsewhere including the ENSO-related tropical Pacific SST.

\section{Response to the WWB and 2015/16 EI Niño}

Here we use AGCM experiments to isolate the roles of El Niño and the northeastern Pacific WWB on the western U.S. climate during the 2015/16 El Niño. We simulate the response to the mature phase of the 2015/16 El Niño both with and without the WWB SST (the region is defined in Fig. 1). A key question is whether the response to the El Niño-related SST was unusual (in that it produced drying over the U.S. Southwest) or whether instead the response to El Niño was to produce wet conditions over the southwestern United States (as expected), but the WWB SST acted to reduce that response.

Two sets of AGCM experiments with prescribed SST were performed, as described in section 2c: experiment NW excludes the northeastern Pacific WWB SST, whereas CTL is a control in which observed SST is specified globally. Figure 4 shows the z250 and precipitation anomalies produced in the control experiment for the 2015/16 winter. The two negative anomalies of z250 over the northeastern Pacific and the southeastern United States, and the weak positive anomalies over the southwestern United States found in the observations (Fig. 3c and contours in Fig. 4a), are to a large extent reproduced by the AGCM simulation (Fig. 4a, shaded). However, a more detailed comparison with the observations (contours in Fig. 4a) shows that the center of the AGCM-produced negative height anomalies over the 

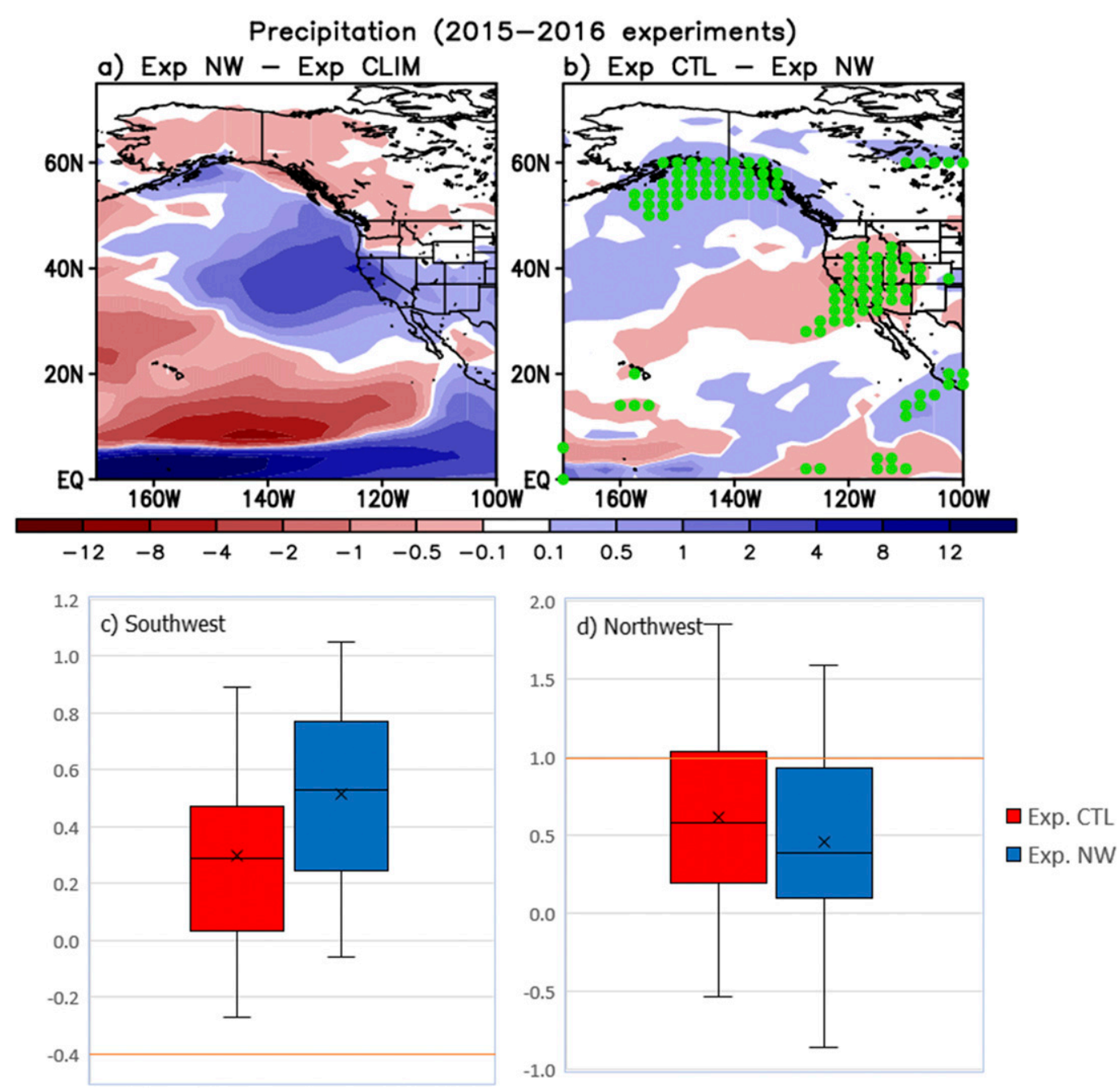

FIG. 5. Precipitation $\left(\mathrm{mm} \mathrm{day}^{-1}\right)$ fields for DJF 2015/16 reproduced by the experiments with precipitation differences from (a) expt NW minus CLIM and (b) CTL minus expt NW, explaining the precipitation change by the addition of the WWB effect to the El Niño effect. Green dots are plotted at the grid points, where the difference between the two ensemble means is significant at the $95 \%$ confidence level, based on the Student's $t$ test. Box-andwhisker plots of the DJF 2015/16 precipitation anomalies from CTL (red) and expt NW (blue) for (c) Southern California, Arizona, and northwestern Mexico $\left(25^{\circ}-37^{\circ} \mathrm{N}, 110^{\circ}-123^{\circ} \mathrm{W}\right)$ and (d) northwestern United States and southwestern Canada $\left(38^{\circ}-55^{\circ} \mathrm{N}, 120^{\circ}-130^{\circ} \mathrm{W}\right)$. Horizontal lines of the boxes denote the 1 st quartile (bottom edge), median (inside boxes), and 3rd quartile (top edge). Crosses inside boxes are the mean, and the whiskers represent spread of model ensemble. Horizontal orange lines are the observed precipitation anomalies.

northeastern Pacific is slightly to the southeast of the observed center of anomalies. It appears that 1) this slight shift in the negative height anomalies and the associated cyclonic circulation anomalies is associated with the overestimation of the precipitation over Southern California, Arizona, and northwestern Mexico (weak positive rather than the observed negative anomalies; compare Figs. 4b and 2f). We also see 2) large difference in precipitation over the eastern United States. We will come back to these discrepancies over the United States in section 5. In contrast, the observed positive anomalies near the coastal line of the northwestern United States and southwestern Canada (Fig. 2f) are faithfully reproduced by the model (Fig. 4b).

The above results are unexpected in that the response to the global SST did not produce the large wet anomalies over the U.S. Southwest expected from the canonical response to tropical Pacific SST anomalies associated with a strong El Niño (cf. Fig. 4b with Figs. 13a and 14a), suggesting SST anomalies in other regions may have played a role in suppressing that response. To address the role of the WWB we turn to experiment NW, in which 


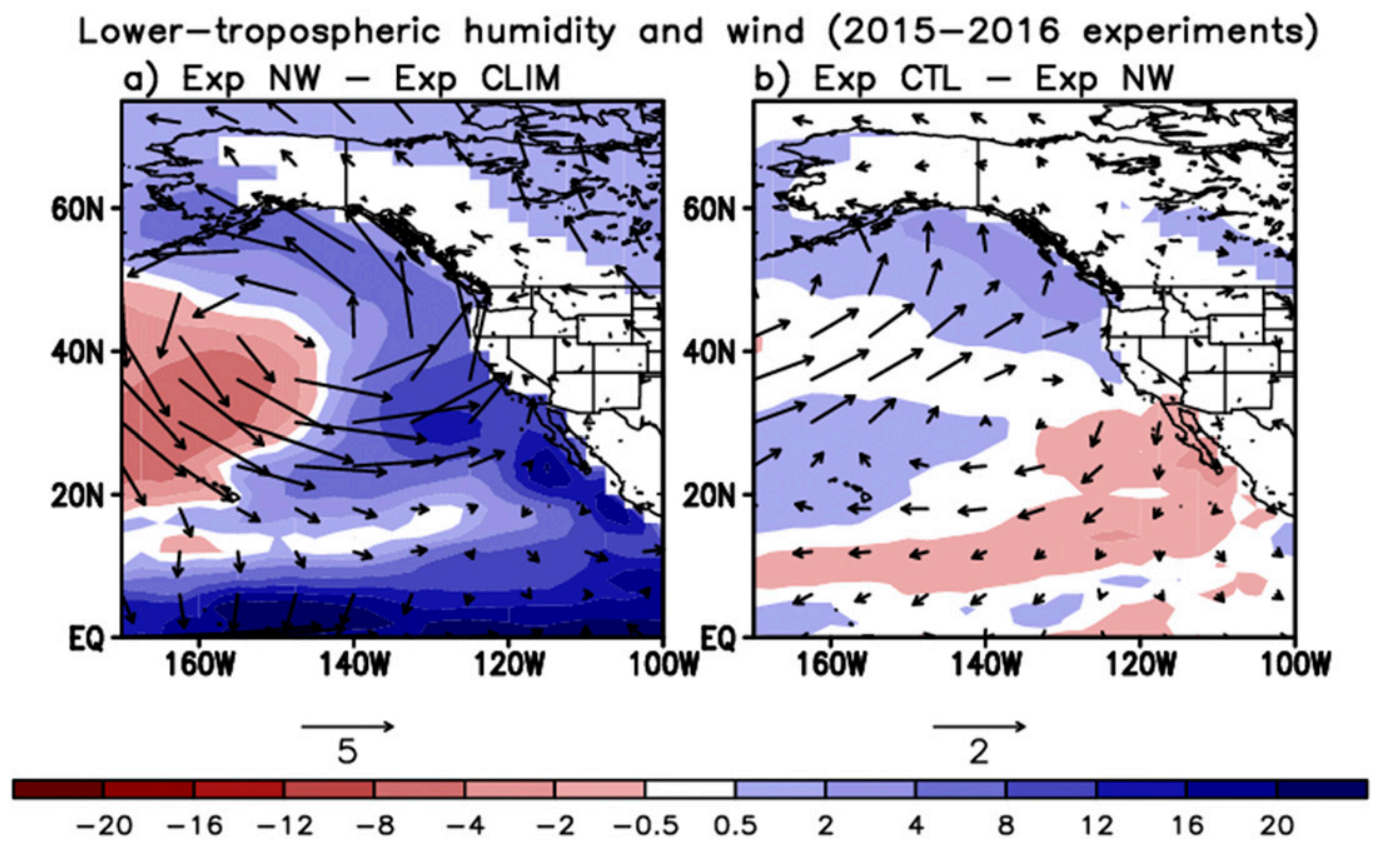

FIG. 6. As in Figs. 5a,b, but for the $850-950-\mathrm{mb}$ averaged specific humidity $\left(10^{-1} \mathrm{~g} \mathrm{~kg}^{-1}\right.$; shaded) and $850-\mathrm{mb}$ horizontal wind $\left(\mathrm{m} \mathrm{s}^{-1}\right.$; vectors).

the WWB SSTs in the northeast Pacific are removed. Figure 5a shows that the precipitation anomalies for the 2015/16 winter season in that run are indeed characterized by positive anomalies over much of the southwestern United States and northwestern Mexico. As we shall see in section 6 , this is primarily the canonical impact from the strong equatorial El Niño SST anomaly (e.g., similarity between Figs. 5a and 13a). The difference in precipitation between experiments CTL and NW shown in Fig. 5b clearly demonstrates that the WWB SSTA modulates the El Niño impact by reducing precipitation over the southwestern United States and part of Mexico.

Figures $5 \mathrm{c}$ and $5 \mathrm{~d}$ summarize the results of the two sets of experiments over the North American southwest $\left(\mathrm{SW} ; 25^{\circ}-37^{\circ} \mathrm{N}, 110^{\circ}-123^{\circ} \mathrm{W}\right)$ and northwest (NW; $\left.38^{\circ}-55^{\circ} \mathrm{N}, 120^{\circ}-130^{\circ} \mathrm{W}\right)$ regions in terms of box-andwhisker plots. Figure 5 highlights the modest drying impact of the WWB over the SW region and wet condition over the NW region. The results (in particular the ensemble spread encompassed by the whiskers) also leave open the possibility that internal variability might have played a role in acting to further counteract the canonical El Niño response in the SW region (we will address that in the next section). It is, however, also clear that even after accounting for internal variability, the model results cannot fully account for the observed anomaly that lies outside the model spread in the SW (Fig. 5c) (although that is not the case over the NW region; Fig. 5d). We will come back to a discussion of the role of model error in section 6 .

The lower-tropospheric wind and moisture distribution in Fig. 6 clarifies how the western North America region responds to El Niño and the WWB. In experiment NW (Fig. 6a), the western North America and eastern Pacific regions are characterized by positive moisture anomalies with a strong onshore moist flow. The inclusion of the WWB SST over the northeastern Pacific (CTL) shifts the distribution of cyclonic circulation anomalies over the northeastern Pacific northward (Fig. 6b). As shown in Fig. 7b, this northward shift is vertically linked to an enhancement of the negative SLP anomaly in response to the WWB SSTA located northward compared to the location of negative SLP anomaly along the western U.S. coast in Fig. 7a, resulting in the enhanced cyclonic circulation anomalies close to the northwestern United States and southwestern Canada in Fig. 7d. Associated with these circulation anomalies, the simulation produces wet conditions (i.e., moist flow from the ocean and a positive humidity anomaly) over the northwestern United States and southwestern Canada (Fig. 6b), which is consistent with the observed positive precipitation anomalies over that region during the 2015/16 winter (e.g., Fig. 2f). At the same time, the anticyclonic circulation anomalies to the south are associated with decreases in moisture over the southwest coast of the United States and Mexico and a weak offshore flow (Fig. 6b). 

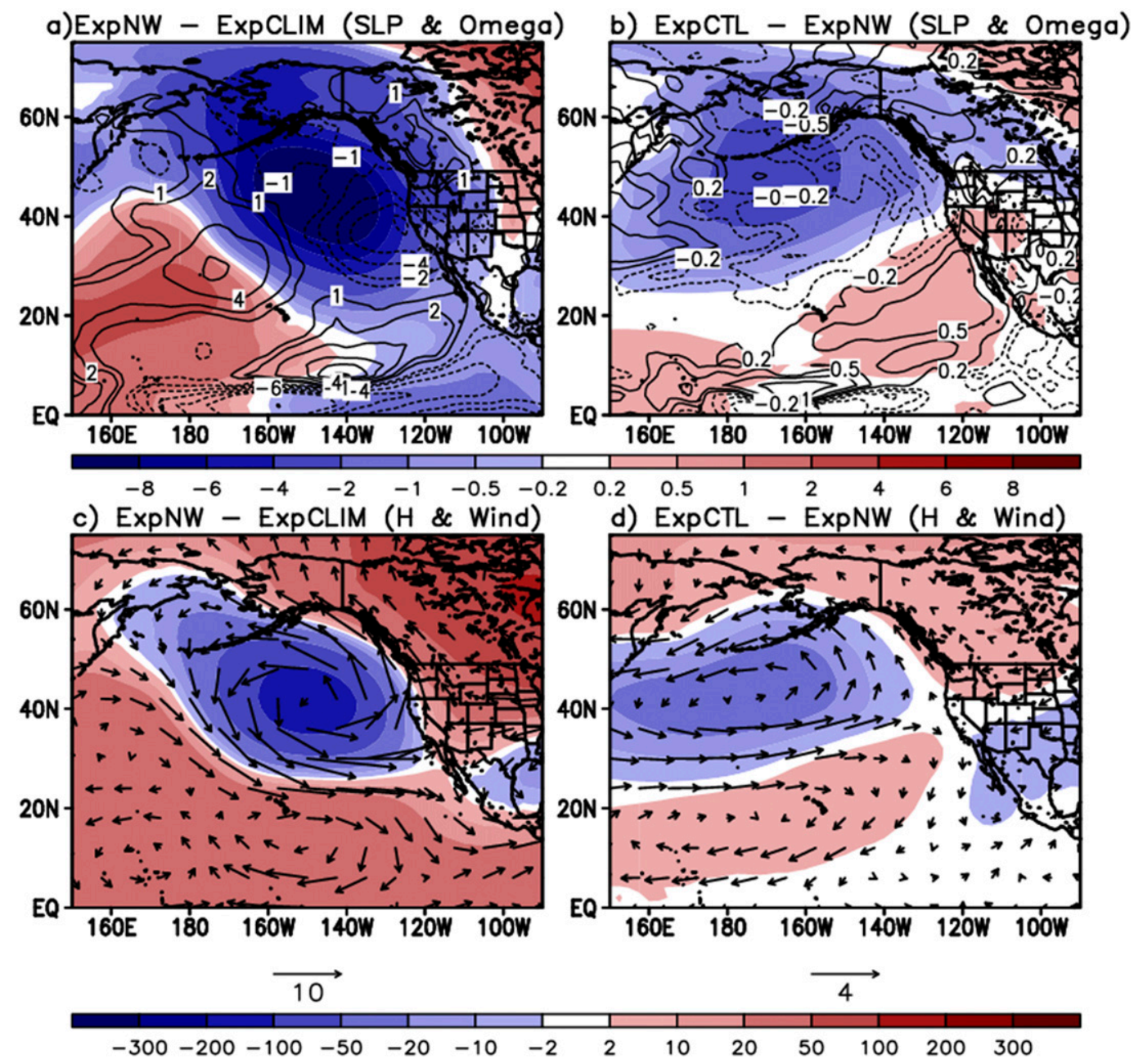

FIG. 7. As in Figs. 5a,b, but for (a),(b) SLP (mb; shaded) and 500-mb vertical pressure velocity $\left(10^{-2} \mathrm{~Pa} \mathrm{~s}^{-1}\right.$ contours) and (c),(d) 500-mb geopotential height (m; shaded) and horizontal circulation ( $\mathrm{m} \mathrm{s}^{-1}$; vectors).

The SLP and upper-tropospheric $(500 \mathrm{mb})$ height and circulation fields also help to clarify how the atmosphere responds to El Niño and the WWB. The SLP field in Fig. 7a shows a strong negative SLP anomaly over the northeastern Pacific with a positive anomaly to the southwest in the subtropical central Pacific. Another positive SLP anomaly is seen over central Canada. Comparing the SLP anomalies to the upperlevel height anomalies (Fig. 7c), one finds a slight westward tilt with height for the anomalies. Ascending motion is found on the southeastern side of the negative SLP anomaly over the Pacific (Fig. 7a), where the upperlevel divergence between trough and ridge is expected. This region is connected with the low-level onshore flow and humid conditions (Fig. 6a), associated with the above average precipitation over the southwestern United States (Fig. 5a).
The atmospheric structures shown in Figs. 7a,c produced in experiment NW are quite consistent with the typical tropospheric response to El Niño. When the effect of the WWB is added (Fig. 7b), there is an increase in SLP over the southwestern U.S. land, and a decrease in SLP and height over the northeastern Pacific. These changes in SLP and height and the corresponding changes in horizontal and vertical motion act to confine the west coast wet anomalies to southwestern Canada and the northwestern United States (e.g., Figs. 5b and 6b).

Figures 5-7, along with quantitative estimation of the precipitation anomalies, overall demonstrate that the WWB acts to counter the El Niño-driven positive precipitation anomalies of $0.5-0.55 \mathrm{~mm} \mathrm{day}^{-1}$ (Fig. 5a) over Southern California and Arizona, and part of northwestern Mexico $\left(25^{\circ}-37^{\circ} \mathrm{N}, 110^{\circ}-123^{\circ} \mathrm{W}\right)$, dropping that amount down to approximately $0.3 \mathrm{~mm}^{-1}$ day $^{-1}$ (Figs. $4 \mathrm{~b}$ and $5 \mathrm{~b}, \mathrm{c}$ ), 

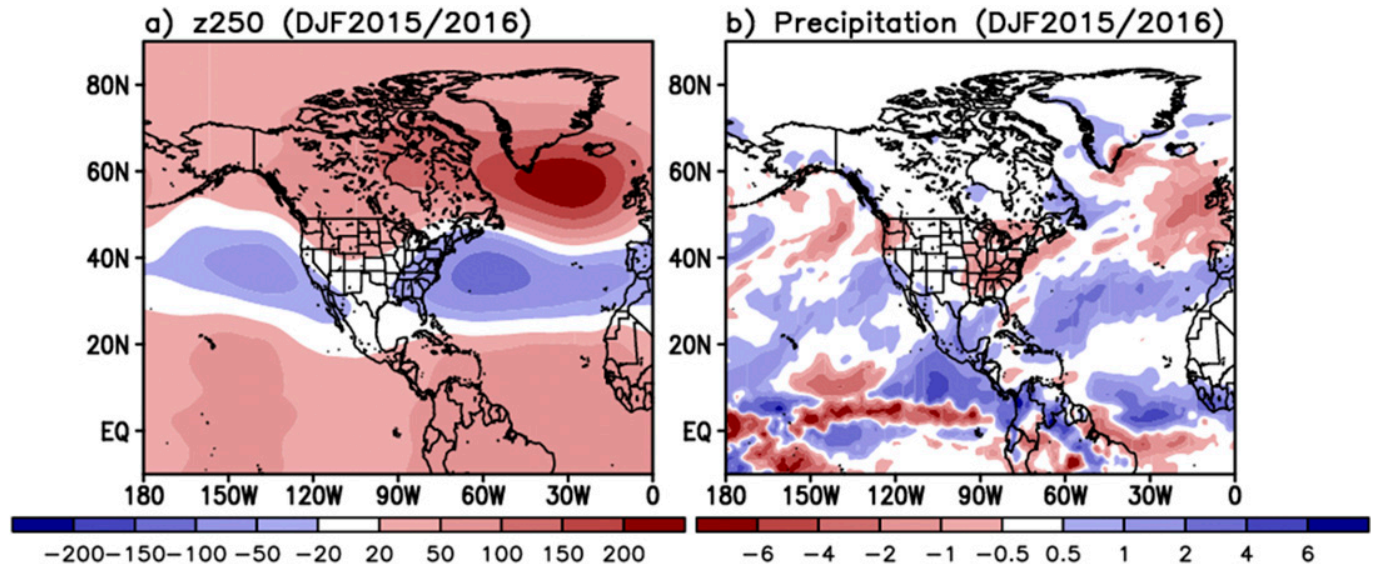

FIG. 8. Differences in (a) z250 (m) and (b) precipitation (mm day-) between the model ensemble mean from expt CTL and observation (model minus observation) for DJF 2015/16.

although this is still insufficient to fully account for the observed negative precipitation anomalies of about $0.4 \mathrm{~mm} \mathrm{day}^{-1}$ below average over that region (Fig. 2f). A significance test confirms that these two ensemble-mean precipitation anomalies (from experiments NW and CTL) are statistically different at $95 \%$ confidence level (indicated by dots in Fig. 5b). In the next section we examine the possible role of unforced atmospheric variability in further contributing to the observed belowaverage precipitation over that region. ${ }^{3}$

\section{The role of unforced atmospheric teleconnections}

In section 4 , we found that precipitation anomalies forced by the WWB are not sufficient to fully counteract the El Niño-driven positive precipitation anomalies simulated by the GEOS-5 AGCM in the southwestern United States (the difference between the ensemble mean of CTL and the observations is shown in Fig. 8b). We also found that the upper-level negative geopotential height anomalies over the northeastern Pacific, while shifted north of those associated with the canonical El Niño response, are nevertheless still southeast of the observed (Fig. 8a). Over the Atlantic sector, the ensemble-mean minus the observed z250 anomaly shows negative anomalies over the southeastern United States and positive anomalies over the northeastern Canada and Greenland, suggesting a possible role of the NAO and/or AO (Fig. 8a).

\footnotetext{
${ }^{3}$ Of course, we cannot rule out the possibility that the discrepancies between the observed and ensemble-mean anomalies in part reflect model deficiencies in the AGCM response to SST.
}

To determine if the differences between observations and the ensemble-mean response reflect contributions from internal modes of variability (i.e., modes unforced by SST), we investigate the intraensemble variability of CTL simulations [following Hoerling and Kumar (1997)]. As shown in Fig. 9a, the intraensemble variance of geopotential height has local maxima over the northeastern Pacific, midlatitude Atlantic, and Greenland areas. Relatively large variance is also seen over the Arctic. Interestingly, the areas of large intraensemble variance are indeed regions in which the NAO and $\mathrm{AO}$ teleconnection patterns are active. Large intraensemble variance of extratropical precipitation is primarily found over the western coastal region of North America and the midlatitude Atlantic (Fig. 9b), consistent with the large variance of upper-level geopotential height over those regions. This suggests the possibility that unforced internal atmospheric noise components could contribute to the observed precipitation anomalies in those regions. We also show in Fig. 9 a rough measure of the signal-to-total variance $(S / T)$ ratio computed as the square of the ensemble-mean anomaly (the part forced by SST) divided by the sum of the square of the ensemble-mean anomaly and intraensemble variance for both the 250-mb geopotential height anomalies (Fig. 9c) and precipitation anomalies (Fig. 9d). This is our estimate of the fraction of the total variance forced by SST in the model results. The $S / T$ values range from 0 to 1 . Values greater than (equal to) 0.5 indicate that the magnitude of the part forced by SST is larger than (equal to) the unpredictable noise. The distribution of the height $S / T$ values highlights the not unexpected large signal relative to the noise in the tropics. In the extratropics, the largest $S / T$ values for the height field occur offshore in the northeastern Pacific and over Canada, 
a) $z 250$ (std.)
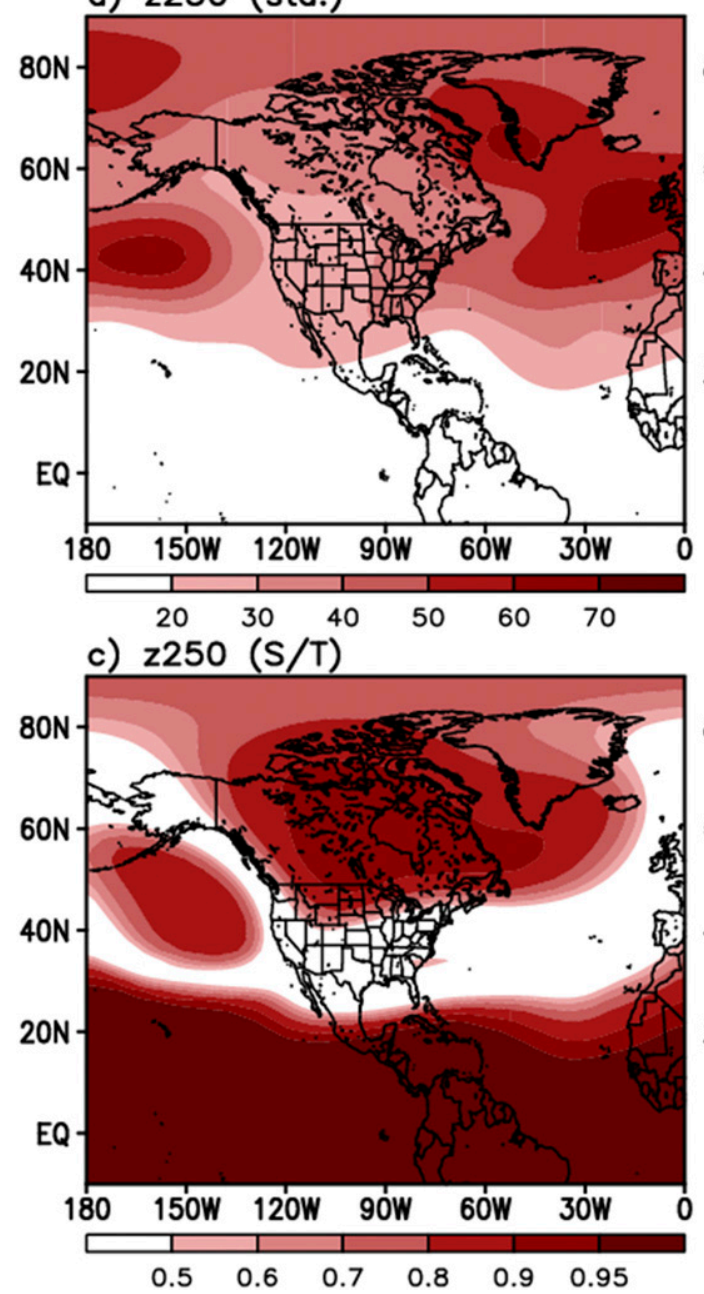

b) Precipitation (std.)

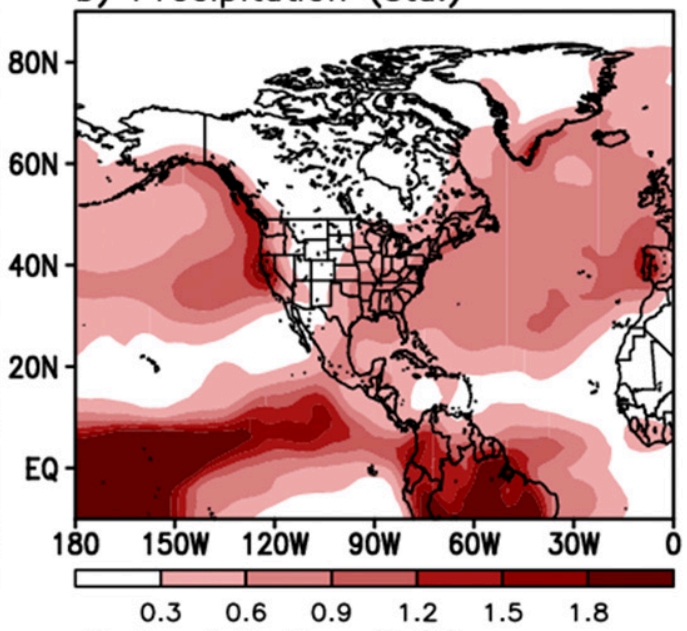

d) Precipitation $(S / T)$

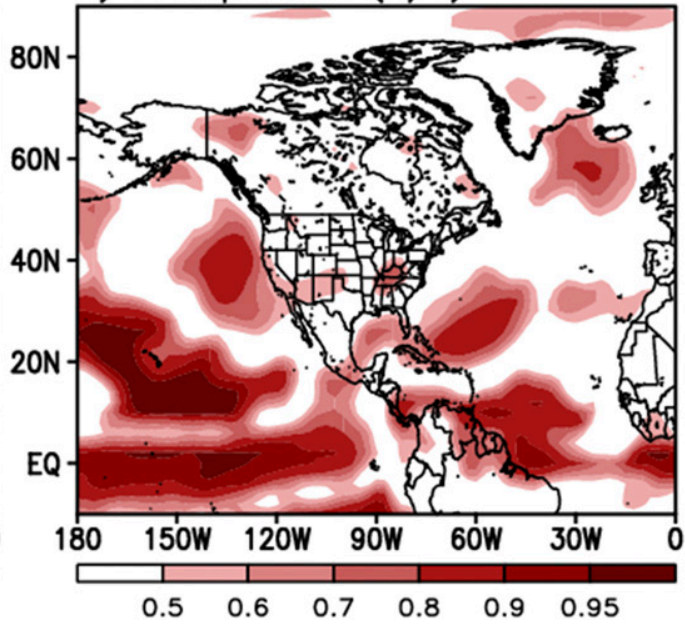

FIG. 9. The intraensemble standard deviation of (a) the $\mathrm{z} 250$ anomalies (m) and (b) precipitation (mm day ${ }^{-1}$ ) from CTL. The ratio of the square of the ensemble-mean anomaly to the total variance [the square of the ensemblemean anomaly (CTL - CLIM) plus the intraensemble variance] of (c) the z250 anomalies and (d) precipitation. Units are dimensionless.

with the latter presumably being important for providing a predictable signal for the steering of storms into the west coast. The $S / T$ ratio for the tropical precipitation shows the largest values just north of the equator near $140^{\circ} \mathrm{W}$. In the middle latitudes a relative maximum occurs just off the west coast, while much of California has values ranging between 0.5 and 0.6. We note that the eastern United States has lower $S / T$ values for precipitation than the southwestern United States (Fig. 9d), suggesting comparatively less predictability in that region.

To demonstrate that unforced internal atmospheric noise does indeed contribute to the observed precipitation anomalies, we next reconstruct the MERRA-2 geopotential height anomalies as a linear combination of the ensemble mean and the leading modes of the unforced atmospheric variability. A rotated empirical orthogonal function (REOF) (Richman 1986) is employed to capture the leading components of the unforced atmospheric variability from all 50 members of CTL. As seen Figs. 10d-f, the two leading modes do represent AO-like and NAO-like anomaly patterns (Figs. 10d,e). The third mode explains large variability across the mid-to-high latitudes, showing some similarity to the NAO. We note that none of the first few leading modes resembles the PNA pattern-suggesting that an influence that could be attributed to a different flavor of ENSO is weak in 2015. We will come back to the issue of the possible impact of a change in the character of ENSO in section 6 (Fig. 13). The three leading modes account for approximately $65 \%$ of the intraensemble variance [ $30 \%$ (first), $23 \%$ (second), and $14 \%$ (third)]. We next use the leading REOFs as 


\section{Reconstructed $z 250$ (DJF2015) from the intra-ensemble variability}

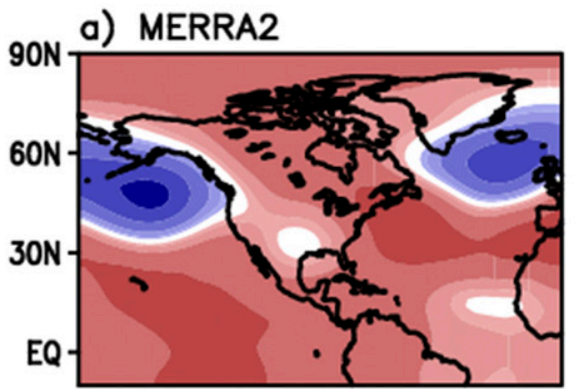

d) REOF 1

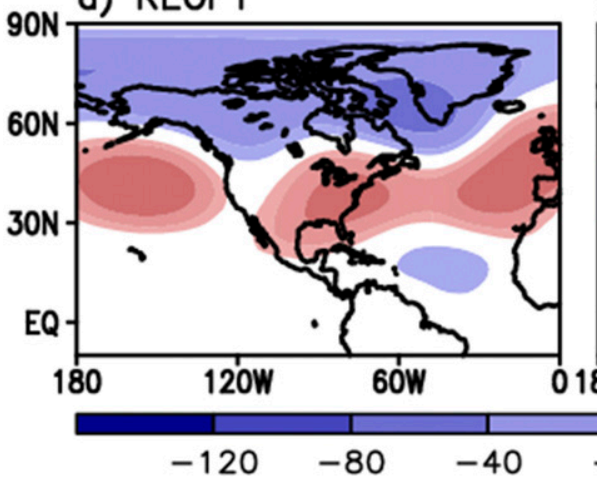

b) EnsM

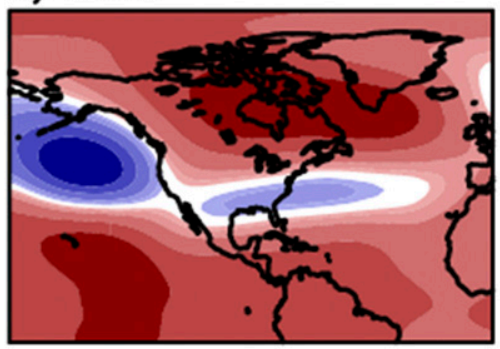

e) REOF2

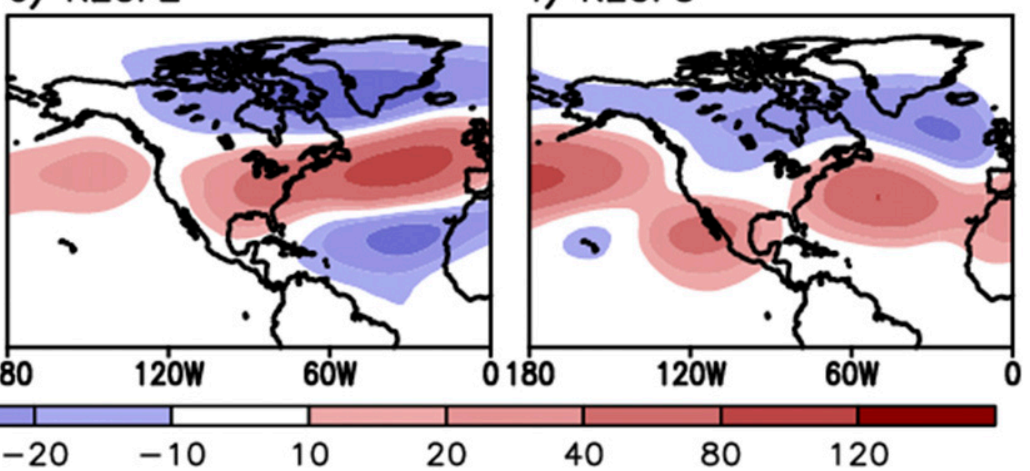

FIG. 10. Distribution of the z250 anomalies (m) from (a) MERRA-2, (b) the model's ensemble mean, and (c) reconstruction as a linear combination of model's ensemble-mean and unforced components of atmospheric variability. (d)-(f) The corresponding leading REOFs (positive phase basis) of those unforced components.

the predictors of the difference between the observed anomaly and the model ensemble-mean anomaly in a regression equation using the approach of Chang et al. (2012). Figure 10c shows the reconstructed geopotential height anomalies as a sum of the ensemble mean and a linear combination of the first three independent leading modes of the unforced atmospheric variability. Comparing Figs. 10a-c, we see that the unforced components of atmospheric variability resembling the $\mathrm{AO}$ and NAO, which are not directly forced by SST (e.g., El Niño and the WWB), can account for a substantial portion of the observed height anomaly that is not reproduced by model's ensemble mean. The fact that very few of the leading modes of the intraensemble variance (together with the ensemble-mean response) reconstruct the observed anomalies reasonably well suggests this is more than just a matter of the REOFs spanning the space of the observed variability, but that these REOFs represent physically realistic modes of variability present at that time (see also the last paragraph in this section regarding the associated precipitation anomalies including the month-to-month changes).

We next consider the intraensemble variability of the precipitation. In this case, rather than computing separate REOFs for the precipitation (which tend to be rather noisy) we simply regress the precipitation on the above leading height REOFs. Figures $11 \mathrm{~d}-\mathrm{f}$ show the precipitation anomalies associated with the leading REOFs of the upper-level geopotential height anomalies (shown in Fig. 10). We find that the positive phases of all three REOFs are associated with negative precipitation anomalies over the California region (McAfee and Russell 2008; Myoung et al. 2015). In particular, the upper-level positive height anomaly associated with the leading AO-like REOF (Fig. 10d) is linked to anomalous anticyclonic circulation and below-average moisture at $850 \mathrm{mb}$ (Fig. 12a) and the positive SLP anomaly and a strong subsidence along the west coast of the United States (Fig. 12b). This leads to below-average precipitation over the southwestern U.S. region. For example, the reconstructed precipitation across Southern California, Arizona, and part of northwestern Mexico $\left(25^{\circ}-37^{\circ} \mathrm{N}, 110^{\circ}-123^{\circ} \mathrm{W}\right)$ in Fig. $11 \mathrm{c}$ demonstrates that the gap $\left(\sim 0.7 \mathrm{~mm} \mathrm{day}^{-1}\right)$ between the observed negative precipitation anomalies (Fig. 11a; $\sim 0.4 \mathrm{~mm} \mathrm{day}^{-1}$ below average) and ensemble-mean anomalies (Fig. 11b; $\sim 0.3 \mathrm{~mm} \mathrm{day}^{-1}$ above average) is narrowed to within $0.2 \mathrm{~mm} \mathrm{day}^{-1}$ (area-averaged difference of $\sim 0.15 \mathrm{~mm}$ day $^{-1}$ ) by the contribution of the unforced components of atmospheric variability. 


\section{Reconstructed Precip. (DJF2015) from the intra-ensemble variability}

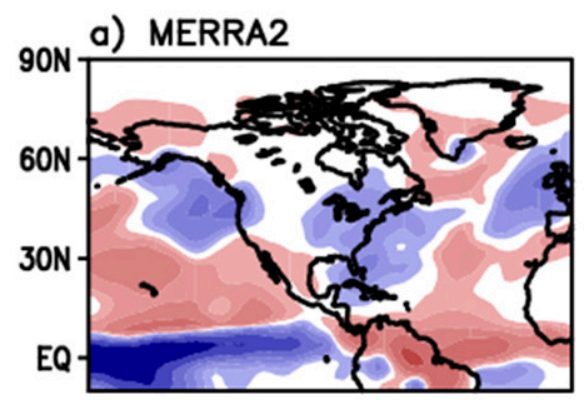

\section{b) EnsM}
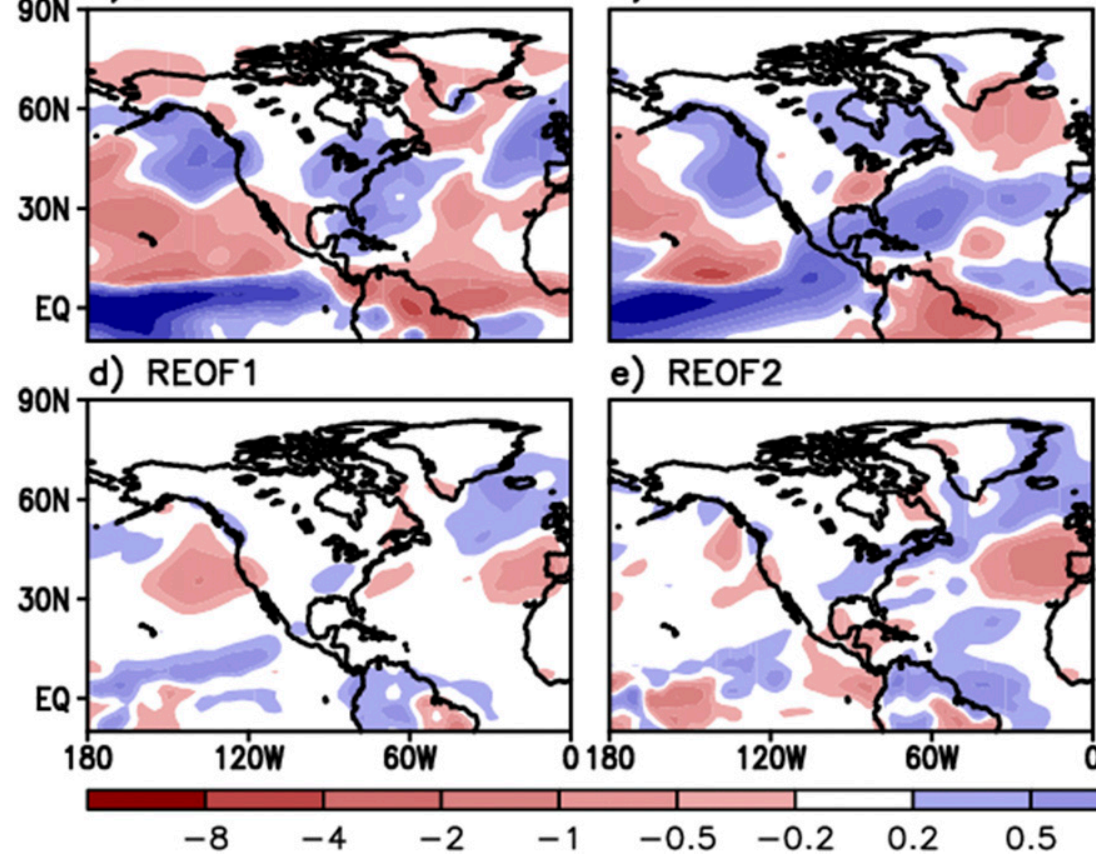

e) REOF2

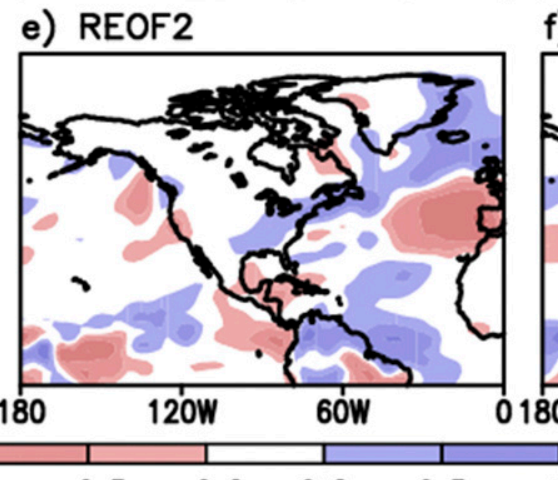

c) Intra Ens.+EnsM

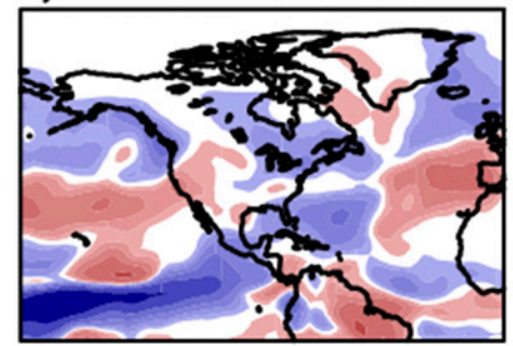

f) REOF3

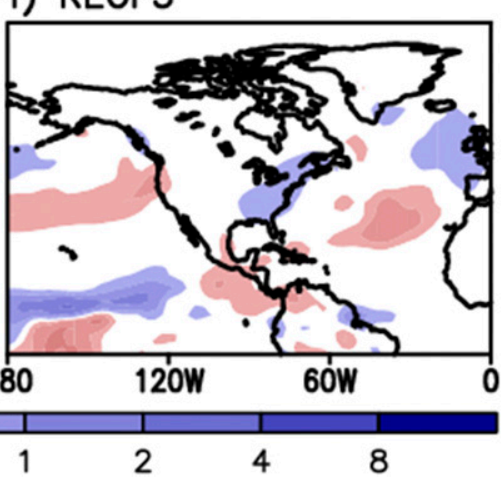

FIG. 11. As in Fig. 10, but for precipitation $\left(\mathrm{mm} \mathrm{day}^{-1}\right)$.

The above model results indicating a key role of unforced internal atmospheric modes of variability resembling the AO and NAO are not inconsistent with their observed phases during the 2015/16 winter. In particular, the indices of the NAO and AO (as provided by the NOAA Climate Prediction Center ${ }^{4}$ ) were both strong positive (2.2 and 1.4, respectively) in December followed by a weak positive phase for the NAO and strong negative phase for the AO in January (0.1 and -1.4). Monthly precipitation (MERRA-2) over the southwestern United States and northwestern Mexico was below average $\left(-0.5 \mathrm{~mm} \mathrm{day}^{-1}\right)$ in December and above average $\left(0.3 \mathrm{~mm} \mathrm{day}^{-1}\right)$ in January, consistent with the expected impacts of the NAO and AO depending on their phases. Precipitation in February again dropped significantly down to $-1.0 \mathrm{~mm} \mathrm{day}^{-1}$. The NAO during that month was in a strong positive phase (1.6), along with near-zero amplitude of the AO (0.0), indicating that precipitation specifically during February 2016 could have been more affected by a positive phase of the NAO.

\footnotetext{
${ }^{4}$ See http://www.cpc.ncep.noaa.gov/products/precip/CWlink/ daily_ao_index/monthly.ao.index.b50.current.ascii.table and http:// www.cpc.ncep.noaa.gov/products/precip/CWlink/pna/norm.nao. monthly.b5001.current.ascii.table.
}

\section{Remaining issues and discussion}

This study employed the MERRA-2 reanalysis and GEOS-5 AGCM simulations with specified SST to investigate the impact on the western U.S. 2015/16 winter climate of large-scale atmospheric teleconnections (both forced and unforced by SST). The AGCM experiments were designed to isolate the contribution from a persistent and strong WWB in the northeastern Pacific, and how that may have impacted the canonical response to a strong $\mathrm{El}$ Niño that was expected to bring (but failed to deliver) much-needed relief to the drought-stricken U.S. Southwest during that winter.

It was found that the atmospheric response to the WWB SST was indeed to decrease the precipitation in the southwestern U.S. region. This was accompanied by a reduction in moist transport, enhanced descending motion, and increased sea level pressure and anticyclonic circulation. In contrast, in the northwestern U.S. region the WWB produced anomalous cyclonic circulation and moist air transport from the Pacific, contributing to the enhancement of precipitation in that region.

It was further shown that, in the absence of the influence of the WWB, the response to the observed SST anomalies in all other regions was to produce wet conditions over the U.S. Southwest, similar to the canonical strong ENSO response. While the impact of the WWB 
a) Moisture \& UV at $850 \mathrm{mb}$

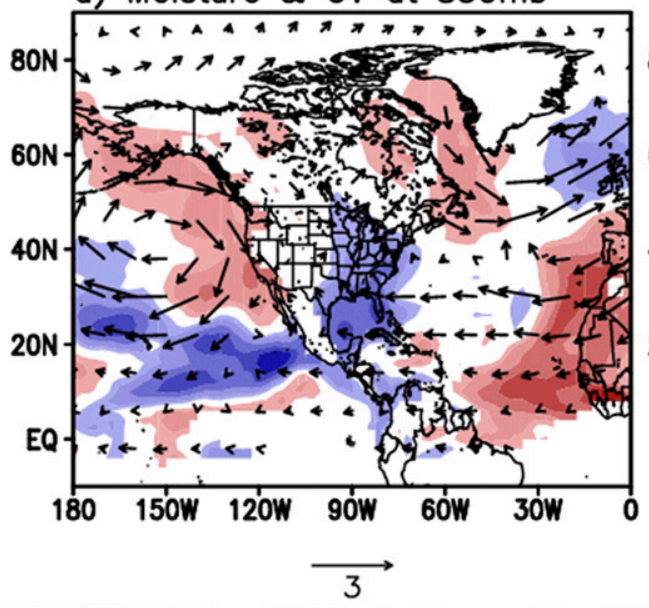

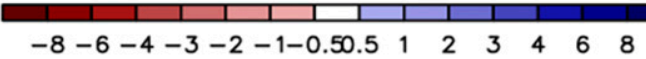

b) SLP \& OMEGA500

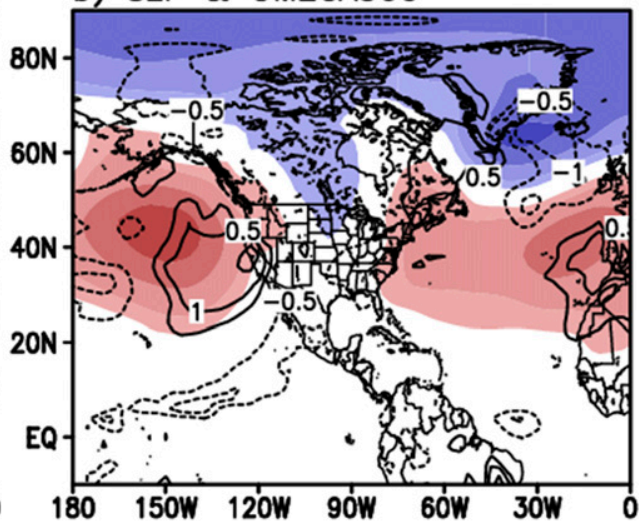

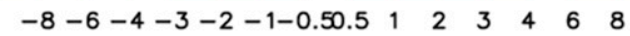

FIG. 12. Regressed REOFs onto the AO-like REOF of the z250 anomalies (Fig. 10d). The key atmospheric variables used for this regression are (a) $850-\mathrm{mb}$ specific humidity $\left(10^{-1} \mathrm{~g} \mathrm{~kg}^{-1}\right.$; shaded) and circulation $\left(\mathrm{m} \mathrm{s}^{-1}\right.$; vectors) and (b) SLP (mb; shaded) and 500-mb vertical pressure velocity $\left(10^{-2} \mathrm{~Pa} \mathrm{~s}^{-1}\right.$; contours).

(as described above) was to counteract the influence of El Niño in the Southwest, the model response to the WWB was not sufficient to fully overcome the relatively large El Niño-driven positive precipitation anomalies. There are a number of possible reasons for this including model errors, although we focused here on the role that unforced (by SST) atmospheric noise may have played in contributing to the precipitation deficit in the Southwest.

We estimated the contribution of the unforced atmospheric variability to the observed precipitation anomalies from the intraensemble variability of the model simulations. The analysis revealed that the leading modes of intraensemble variability of the $250-\mathrm{mb}$ height field have well-defined large-scale structures (with generally north-south-oriented anomalies) that have some resemblance to the NAO and the AO patterns. It was further shown via a regression analysis that the three leading modes (together with the ensemble mean) could reproduce the observed height anomalies reasonably well, including the position of the negative anomaly in the northeastern Pacific - a feature critical for obtaining the correct precipitation anomalies along the North American west coast. In fact, regressing the intraensemble variance of the precipitation against the leading height a) $\operatorname{Exp} \mathrm{SC}-\mathrm{A}$

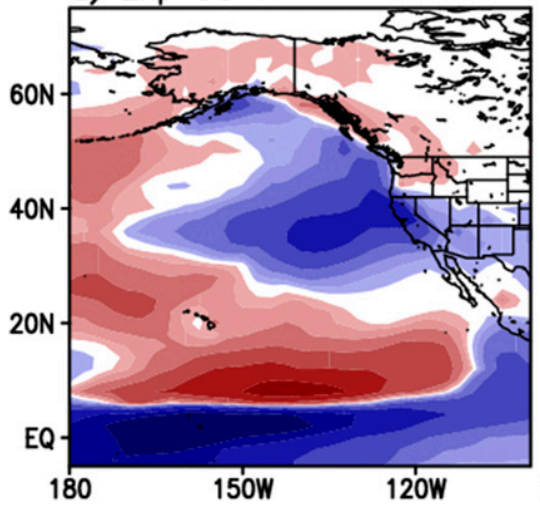

b) $\operatorname{Exp} \mathrm{SC}-\mathrm{B}$

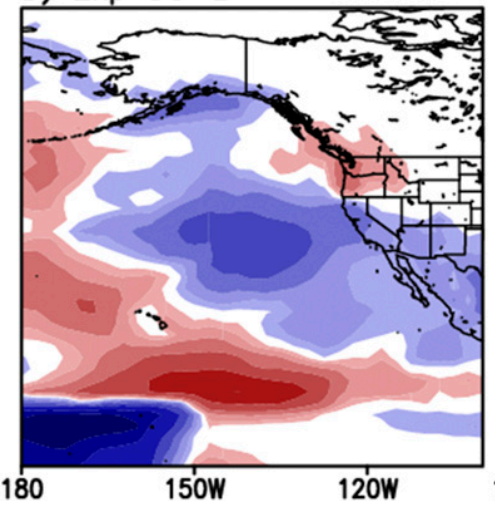

c) $\operatorname{Exp} \mathrm{SC}-\mathrm{C}$

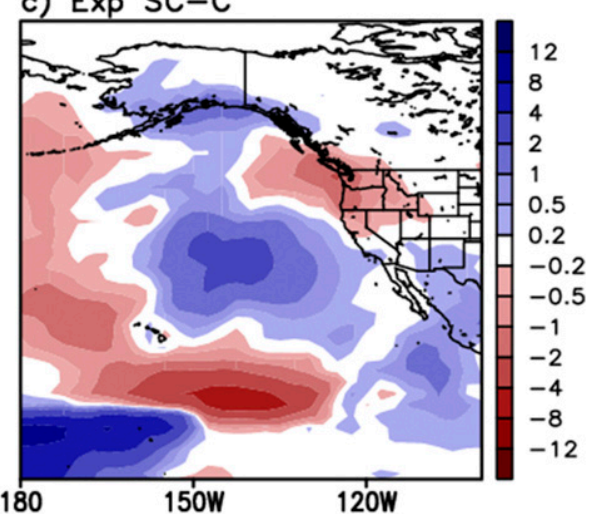

FIG. 13. Precipitation anomalies $\left(\mathrm{mm} \mathrm{day}^{-1}\right)$ for DJF period produced by the "sensitivity to character" experiments (SC; see section $2 \mathrm{c}$ and Table 1). SC-A is the experiment with observed 2015/16 SST prescribed over the tropical Pacific $\left(10^{\circ} \mathrm{S}-20^{\circ} \mathrm{N}\right)$ only. SC-B is the same as SC-A, but for prescribing observed $2015 / 16$ SST over the central tropical Pacific $\left(160^{\circ} \mathrm{E}-150^{\circ} \mathrm{W}\right.$; Niño- 4 region $)$ only. SC-C is the same as SC-B, but for observed SST composite over the central tropical Pacific from historic CP El Niño events that occurred in 1987, 1991, 1994, 2002, 2004, and 2009. SSTs everywhere else are climatology. Shown are precipitation anomalies of (a) SC-A minus CLIM, (b) SC-B minus CLIM, and (c) SC-C minus CLIM. 


\section{Precipitation in DJF Left: strong El Nino, 1997/98, Right: all El Nino}
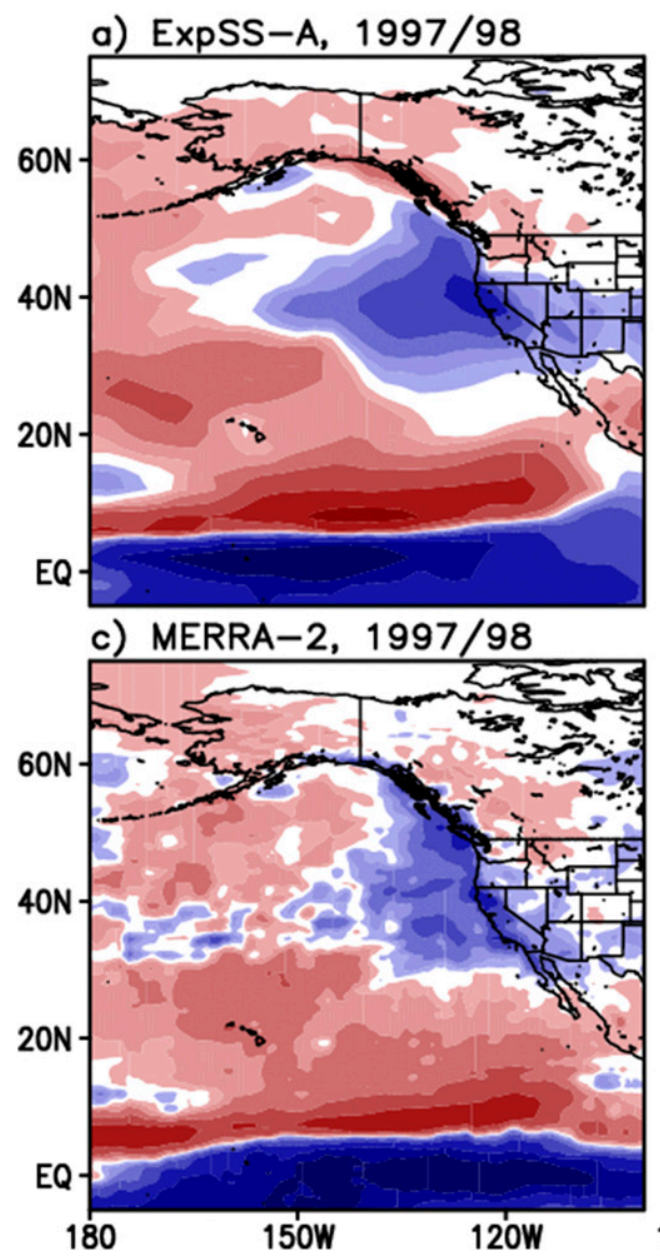

b) ExpSS-B, all El Nino

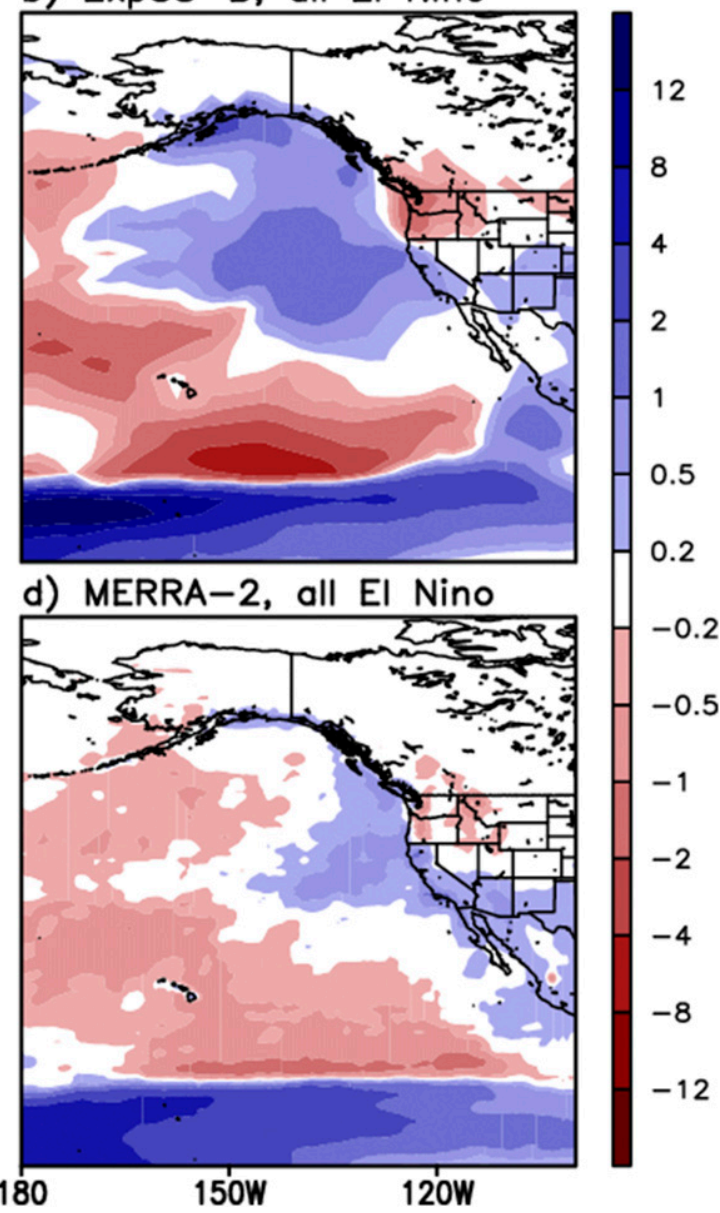

FIG. 14. Comparison in DJF precipitation anomalies $\left(\mathrm{mm} \mathrm{day}^{-1}\right)$ between (a),(b) model simulations (SS; see section 2c and Table 1) and (c),(d) MERRA-2. The precipitation (left) for a strong 1997/98 El Niño [SS-A in (a)] and (right) for all historic El Niño composite (1982, 1986, 1987, 1991, 1994, 1997, 2002, 2004, 2006, and 2009) [SS-B in (b)].

modes produced precipitation anomalies that did much to close the gap between the observed and ensemble-mean response, especially in the U.S. Southwest where the AOlike and NAO-like leading noise pattern seem to play a key role.

To further bolster the above conclusions, a number of additional experiments were carried out to address issues concerning the sensitivity of the response to the character of the tropical Pacific SST, and the realism of the GEOS-5 AGCM response to El Niño.

The sensitivity of the response to the character of the tropical Pacific SST (i.e., the role of the different flavors of El Niño) was addressed with SC (see Table 1 and description in section 2c). While the maximum SST anomalies in the equatorial Pacific did extend into the
CP during 2015/16, a strong SST warming signal nevertheless also existed in the eastern Pacific. Figure 13b shows that even when the 2015/16 tropical Pacific SSTs are confined to only those in the $\mathrm{CP}$ (with climatological SST everywhere else), positive precipitation anomalies were produced over California. This is in contrast to the response to the canonical CP El Niño (Fig. 13c), which produces much weaker (slightly positive) precipitation anomalies over California. We note that the eastern part of CP SST $\left(180^{\circ}-150^{\circ} \mathrm{W}\right)$ is larger in $2015 / 16$ than in the historic CP El Niño events, while the historic CP El Niño has larger warming than 2015/16 over the western part $\left(160^{\circ} \mathrm{E}-180^{\circ}\right)$ (figure not shown). As such, the 2015/16 event was not a typical CP El Niño, although the maximum equatorial warming extended into the $\mathrm{CP}$ as noted 

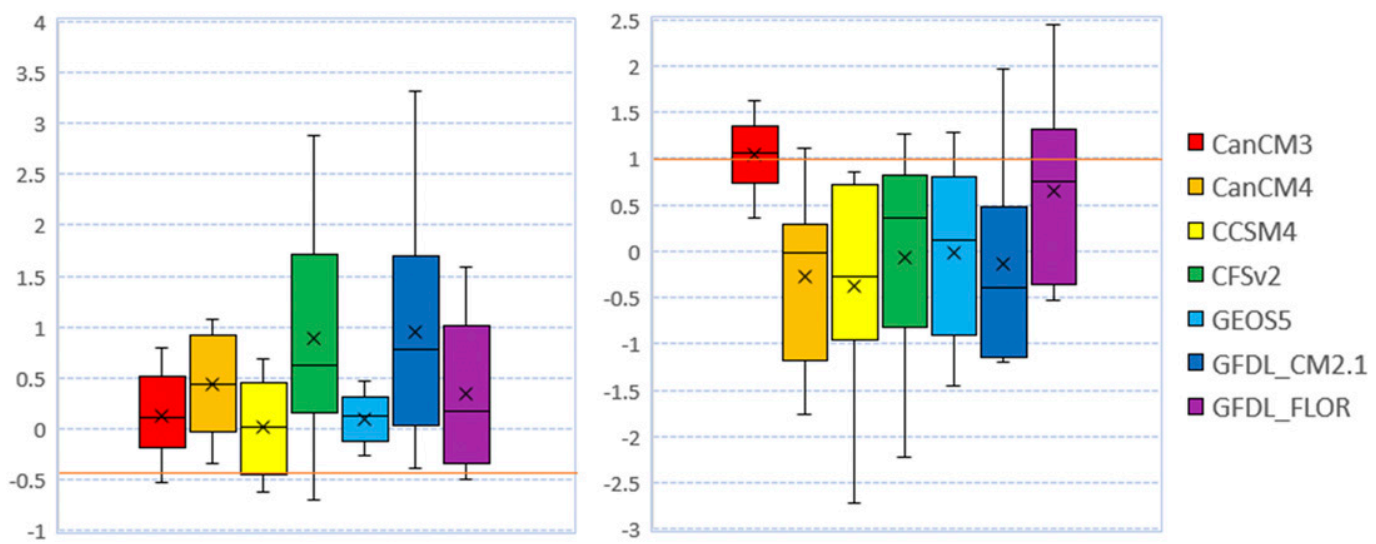

FIG. 15. Box-and-whisker plots of the predicted DJF 2015/16 precipitation anomalies (initialized in November; mm day $^{-1}$ ) from the NMME participating models. (left) The precipitation anomaly for Southern California, Arizona, and northwestern Mexico $\left(25^{\circ}-37^{\circ} \mathrm{N}, 110^{\circ}-123^{\circ} \mathrm{W}\right)$, and (right) the precipitation anomaly for northwestern United States and southwestern Canada $\left(38^{\circ}-55^{\circ} \mathrm{N}, 120^{\circ}-130^{\circ} \mathrm{W}\right)$. Horizontal lines in the boxes denote the 1 st quartile (bottom edge), median (inside boxes), and 3rd quartile (top edge). Crosses inside boxes are the mean, and the whiskers represent spread of model ensemble. Horizontal orange lines are the observed precipitation anomalies.

above. Based on these results we conclude that the specific character (spatial distribution) of the tropical Pacific warming in 2015/16 is not a main cause of the negative precipitation anomalies in California.

To assess the realism of the AGCM's response to the strength of the tropical El Niño SST we carried out two additional sets of runs (SS; see Table 1 and the description in section 2c), one in which the prescribed SST consisted of those from the 1997/98 El Niño (also a strong event but without a WWB) and another in which they consisted of an El Niño composite (the average of the years 1982, 1986, 1987, 1991, 1994, 1997, 2002, 2004, 2006, and 2009). The results (Fig. 14) show that during the strong 1997/98 El Niño the precipitation over the southwestern United States is substantially above average, consistent with the observations (cf. Figs. 14a,c). Negative precipitation anomalies are produced over part of the northwestern United States and western Canada in both the simulation and observations (Figs. 14a,c). For the case of the El Niño composite SST, the model precipitation again shows positive anomalies over the southwestern United States with negative anomalies over the northwestern United States (Fig. 14b), although the magnitude of the wet anomaly over the southwestern United States is somewhat smaller than for the strong El Niño case (Figs. 14a,b). The distribution of the simulated precipitation anomalies is again quite realistic (cf. Figs. 14b,d). These results support our contention that the GEOS-5 AGCM responds reasonably well to El Niño SST strength, especially with respect to the wet conditions over the southwestern United States.

There is of course the more general question as to what extent model deficiencies may be impacting our conclusions. While we have shown that the combination of the response to the WWB and internal variability atmospheric variability acts to partly counter the precipitation response over the southwestern United States to the tropical El Niño SST, the observed precipitation anomaly, nevertheless, falls outside the 50-member ensemble spread (Fig. 5c), indicating that model errors are also playing a role (Siler et al. 2017). This could for example be the result of bias in tropical convection (Fig. 8b) that forces zonally elongated midlatitude height and circulation anomalies explaining some of height differences between the observed and ensemble-mean anomaly in the midlatitudes in Fig. 8a (e.g., Hoerling and Kumar 2003; Seager et al. 2003; Lau et al. 2008). We also cannot rule out the possibility that the GEOS-5 model did not respond properly to non-ENSO tropical forcing such as that over the warm pool/Indian Ocean, which has been shown to impact California precipitation (Seager et al. 2015).

The above discussion also gets to the question of predictability and prediction skill, and why almost all coupled models [including those from the North American Multi-Model Ensemble (NMME) and the International Multi-Model Ensemble (IMME)] did not predict the continuation of the drought in Southern California (based on the ensemble averages), and in fact predicted the exact opposite (i.e., that there would be substantial relief from the drought in the form of positive precipitation anomalies presumably forced by the very strong El Niño-related tropical Pacific SST). To get further clarity on the NMME predictions, Fig. 15 shows box-and-whisker plots (analogous to Figs. 5c,d) for the SW and NW regions for seven of the NMME models. The results are for DJF 2015/16 for 
1-month lead time and are based on 10 ensemble members for each model (https://iridl.ldeo.columbia.edu/ SOURCES/.Models/.NMME). Focusing on the SW region, we see that all the models produce ensemble means that are positive (or near zero) with however several models having an ensemble spread large enough to encompass the observations. The differences among the models both in terms of the ensemble mean and spread suggest that model deficiencies are likely playing a role; however, consistent with our AGCM results, internal atmospheric variability could account for at least part of the observed anomaly. Regarding the role of the WWB, an inspection of the NMME SST predictions in the northeastern Pacific (http:/www.cpc.ncep.noaa.gov/products/ NMME/archive/2015110800/current/tmpsfc_Seas1.html) indicates these are reasonably well predicted at 1-month lead, suggesting that any such impact is likely well simulated by the NMME models [as found in our AGCM results (CTL)], and therefore it is unlikely that deficiencies in the response to the WWB can account for the discrepancies in the precipitation responses.

Overall, the NMME results are not inconsistent with our results concerning the importance of internal atmospheric variability over the southwestern United States during the winter of 2015/16. As such, the fact that none of the NMME models predicted the negative precipitation anomalies (forecasting instead the strong and predictable response to the tropical Pacific SST forcing) is not too surprising, and may not represent a failure of the forecasts, but rather a failure to adequately provide the community with a quantifiable and understandable measure of the uncertainty in the predictions.

Acknowledgments. This work is supported by the NASA Modeling, Analysis, and Prediction (MAP) Program. The authors are grateful to anonymous reviewers for their helpful comments and suggestions.

\section{REFERENCES}

Ashok, K., S. K. Behera, S. A. Rao, H. Weng, and T. Yamagata, 2007: El Niño Modoki and its possible teleconnections. J. Geophys. Res., 112, C11007, https://doi.org/10.1029/2006JC003798.

Bacmeister, J. T., and G. Stephens, 2011: Spatial statistics of likely convective clouds in CloudSat data. J. Geophys. Res., 116, D04104, https://doi.org/10.1029/2010JD014444.

_ - M. J. Suarez, and F. R. Robertson, 2006: Rain reevaporation, boundary layer-convection interactions, and Pacific rainfall patterns in an AGCM. J. Atmos. Sci., 63, 3383-3403, https:// doi.org/10.1175/JAS3791.1.

Barahona, D., A. M. Molod, J. Bacmeister, A. Nenes, A. Gettelman, H. Morrison, V. Phillips, and A. Eichmann, 2014: Development of two-moment cloud microphysics for liquid and ice within the NASA Goddard Earth Observing System Model (GEOS-5). Geosci. Model Dev., 7, 1733-1766, https://doi.org/10.5194/ gmd-7-1733-2014.
Barnston, A. G., R. E. Livezey, and M. S. Halpert, 1991: Modulation of Southern Oscillation-Northern Hemisphere mid-winter climate relationships by the QBO. J. Climate, $\mathbf{4}$ 203-217, https://doi.org/10.1175/1520-0442(1991)004<0203: MOSONH $>2.0$.CO;2.

Barsugli, J. J., and P. D. Sardeshmukh, 2002: Global atmospheric sensitivity to tropical SST anomalies throughout the IndoPacific basin. J. Climate, 15, 3427-3442, https://doi.org/ 10.1175/1520-0442(2002)015<3427:GASTTS > 2.0.CO;2.

Bell, G. D., M. Halpert, and M. L'Heureux, 2016: ENSO and the tropical Pacific [in "State of the Climate in 2015"]. Bull. Amer. Meteor. Soc., 97 (8), S93-S98, https://doi.org/10.1175/ 2016BAMSStateoftheClimate.1.

Blunden, J., and D. S. Arndt, Eds., 2016: State of the Climate in 2015. Bull. Amer. Meteor. Soc., 97 (8), S1-S275, https://doi.org/ 10.1175/2016BAMSStateoftheClimate.1.

Bond, N. A., M. F. Cronin, H. Freeland, and N. Mantua, 2015: Causes and impacts of the 2014 warm anomaly in the NE Pacific. Geophys. Res. Lett., 42, 3414-3420, https://doi.org/ 10.1002/2015GL063306.

Bosilovich, M. G., and Coauthors, 2015: MERRA-2: Initial evaluation of the climate. NASA/TM-2015-104606, Vol. 43, 139 pp.

Cai, W., and Coauthors, 2014: Increasing frequency of extreme El Niño events due to greenhouse warming. Nat. Climate Change, 4, 111-116, https://doi.org/10.1038/nclimate2100.

Capotondi, A., and Coauthors, 2015: Understanding ENSO diversity. Bull. Amer. Meteor. Soc., 96, 921-938, https://doi.org/ 10.1175/BAMS-D-13-00117.1.

Cayan, D. R., K. T. Redmond, and L. G. Riddle, 1999: ENSO and hydrologic extremes in the western United States. J. Climate, 12, 2881-2893, https://doi.org/10.1175/1520-0442(1999)012<2881: EAHEIT > 2.0.CO;2.

Chang, Y., S. D. Schubert, and M. Suarez, 2012: Attribution of the extreme U.S. East Coast snowstorm activity of 2010. J. Climate, 25, 3771-3791, https://doi.org/10.1175/JCLI-D-11-00353.1.

Di Lorenzo, E. D., and N. Mantua, 2016: Multi-year persistence of the 2014/15 North Pacific marine heatwave. Nat. Climate Change, 6, 1042-1047, https://doi.org/10.1038/nclimate3082.

Donlon, C. J., M. Martin, J. D. Stark, J. Roberts-Jones, E. Fiedler, and W. Wimmer, 2011: The Operational Sea Surface Temperature and Sea Ice analysis (OSTIA). Remote Sens. Environ., 116, 140-158, https://doi.org/10.1016/j.rse.2010.10.017.

Garfinkel, C. I., and D. L. Hartmann, 2008: Different ENSO teleconnections and their effects on the stratospheric polar vortex. J. Geophys. Res., 113, D18114, https://doi.org/10.1029/ 2008JD009920.

Ge, Y., G. Gong, and A. Frei, 2009: Physical mechanisms linking the winter Pacific-North American teleconnection pattern to spring North American snow depth. J. Climate, 21, 5135-5148, https://doi.org/10.1175/2009JCLI2842.1.

Gelaro, R., and Coauthors, 2017: The Modern-Era Retrospective Analysis for Research and Applications, version-2 (MERRA-2). J. Climate, 30, 5419-5454, https://doi.org/ 10.1175/JCLI-D-16-0758.1.

GMAO, 2015a: MERRA-2 tavgM_2d_slv_Nx: 2d, Monthly mean, time-averaged, single-level, assimilation, assimilated meteorological fields, version 5.12.4, Global Modeling and Assimilation Office, Goddard Space Flight Center Distributed Active Archive Center (GSFC DAAC), accessed November 2016, https://doi.org/10.5067/AP1B0BA5PD2K.

, 2015b: MERRA-2 tavgM_2d_flx_Nx: 2d, Monthly mean, timeaveraged, single-level, assimilation, surface flux diagnostics, 
version 5.12.4, Global Modeling and Assimilation Office, Goddard Space Flight Center Distributed Active Archive Center (GSFC DAAC), accessed November 2016, https://doi.org/ 10.5067/0JRLVL8YV2Y4.

__ 2015c: MERRA-2 instM_3d_asm_Np: 3d, Monthly mean, instantaneous, pressure-level, assimilation, assimilated meteorological fields, version 5.12.4, Global Modeling and Assimilation Office, Goddard Space Flight Center Distributed Active Archive Center (GSFC DAAC), accessed November 2016, https://doi.org/10.5067/2E096JV59PK7.

Hoell, A., M. Hoerling, J. Eischeid, K. Wolter, R. Dole, J. Perlwitz, T. Xu, and L. Cheng, 2016: Does El Niño intensity matter for California precipitation? Geophys. Res. Lett., 43, 819-825, https://doi.org/10.1002/2015GL067102.

Hoerling, M. P., and A. Kumar, 1997: Why do North American climate anomalies differ from one El Niño event to another? Geophys. Res. Lett., 24, 1059-1062, https://doi.org/10.1029/97GL00918.

- , and - 2003: The perfect ocean for drought. Science, 299, 691-694, https://doi.org/10.1126/science.1079053.

— $—$, and M. Zhong, 1997: El Niño, La Niña, and the nonlinearity of their teleconnections. J. Climate, 10, 1769-1786, https://doi.org/ 10.1175/1520-0442(1997)010<1769:ENOLNA > 2.0.CO;2.

Hu, Z.-Z., A. Kumar, B. Jha, J. Zhu, and B. Huang, 2017: Persistence and predictions of the remarkable warm anomaly in the northeastern Pacific Ocean during 2014-16. J. Climate, 30, 689-702, https://doi.org/10.1175/JCLI-D-16-0348.1.

Huang, B., M. L'Heureux, Z.-Z. Hu, and H.-M. Zhang, 2016: Ranking the strongest ENSO events while incorporating SST uncertainty. Geophys. Res. Lett., 43, 9165-9172, https:// doi.org/10.1002/2016GL070888

Jong, B.-T., M. Ting, and R. Seager, 2016: El Niño's impact on California precipitation: seasonality, regionality, and El Niño intensity. Environ. Res. Lett., 11, 054021, https://doi.org/ 10.1088/1748-9326/11/5/054021.

Kamae, Y., and Coauthors, 2017: Forced response and internal variability of summer climate over western North America. Climate Dyn., 49, 403-417, https://doi.org/10.1007/s00382-016-3350-x.

Kao, H.-Y., and J.-Y. Yu, 2009: Contrasting eastern-Pacific and central-Pacific types of ENSO. J. Climate, 22, 615-632, https:// doi.org/10.1175/2008JCLI2309.1.

Kim, S. T., and J.-Y. Yu, 2012: The two types of ENSO in CMIP5 models. Geophys. Res. Lett., 39, L11704, https://doi.org/10.1029/ 2012GL052006.

Koster, R. D., M. J. Suarez, A. Ducharne, M. Stieglitz, and P. Kumar, 2000: A catchment-based approach to modeling land surface processes in a general model: 1. Model structure. J. Geophys. Res., 105, 24 809-24 822, https://doi.org/10.1029/2000JD900327.

Kug, J.-S., F.-F. Jin, and S.-I. An, 2009: Two types of El Niño events: Cold tongue El Niño and warm pool El Niño. J. Climate, 22, 1499-1515, https://doi.org/10.1175/2008JCLI2624.1.

Larkin, N. K., and D. E. Harrison, 2005: Global seasonal temperature and precipitation anomalies during El Niño autumn and winter. Geophys. Res. Lett., 32, L16705, https://oi.org/10.1029/ 2005 GL022860.

Lau, N.-C., A. Leetmaa, and M. J. Nath, 2008: Interactions between the responses of North American climate to El Niño-La Niña and to the secular warming trend in the Indian-western Pacific Oceans. J. Climate, 21, 476-494, https://doi.org/10.1175/2007JCLI1899.1.

Leathers, D. J., B. Yarnal, and M. A. Palecki, 1991: The Pacific/ North American teleconnection pattern and United States climate. Part I: Regional temperature and precipitation associations. J. Climate, 4, 517-528, https://doi.org/10.1175/ 1520-0442(1991)004<0517:TPATPA > 2.0.CO;2.
L'Heureux, M., and Coauthors, 2017: Observing and predicting the 2015-16 El Niño. Bull. Amer. Meteor. Soc., 98, 1363-1382, https://doi.org/10.1175/BAMS-D-16-0009.1.

Lim, Y.-K., S. D. Schubert, O. Reales, M.-Y. Lee, A. M. Molod, and M. J. Suarez, 2015: Sensitivity of tropical cyclones to parameterized convection in the NASA GEOS-5 model. J. Climate, 28, 551-573, https://doi.org/10.1175/JCLI-D-14-00104.1.

, R. Kovach, S. Pawson, and G. Vernieres, 2017: The 2015/16 El Niño event in context of the MERRA-2 reanalysis: A comparison of the tropical Pacific with 1982/83 and 1997/98. J. Climate, 30, 4819-4842, https://doi.org/10.1175/JCLI-D-16-0800.1.

Mantua, N. J., S. R. Hare, Y. Zhang, J. M. Wallace, and R. C. Francis, 1997: A Pacific interdecadal climate oscillation with impacts on salmon production. Bull. Amer. Meteor. Soc., 78, 1069-1079, https://doi.org/10.1175/1520-0477(1997) 078<1069:APICOW >2.0.CO;2.

McAfee, S. A., and J. L. Russell, 2008: Northern annular mode impact on spring climate in the western United States. Geophys. Res. Lett., 35, L17701, https://doi.org/10.1029/2008GL034828.

Mo, K., 2010: Interdecadal modulation of the impact of ENSO on precipitation and temperature over the United States. J. Climate, 23, 3639-3656, https://doi.org/10.1175/2010JCLI3553.1.

- and R. E. Livezey, 1986: Tropical-extratropical geopotential height teleconnections during the Northern Hemisphere winter. Mon. Wea. Rev., 114, 2488-2515, https://doi.org/10.1175/ 1520-0493(1986)114<2488:TEGHTD>2.0.CO;2.

Molod, A. M., L. Takacs, M. Suarez, and J. Bacmeister, 2015: Development of the GEOS-5 atmospheric general circulation model: Evolution from MERRA to MERRA2. Geosci. Model Dev., 8, 1339-1356, https://doi.org/10.5194/gmd-8-1339-2015.

Moorthi, S., and M. J. Suarez, 1992: Relaxed Arakawa-Schubert: A parameterization of moist convection for general circulation models. Mon. Wea. Rev., 120, 978-1002, https://doi.org/ 10.1175/1520-0493(1992)120<0978:RASAPO > 2.0.CO;2.

Myoung, B., S.-H. Kim, J. Kim, and M. C. Kafatos, 2015: On the relationship between the North Atlantic Oscillation and early warm season temperatures in the southwestern United States. J. Climate, 28, 5683-5698, https://doi.org/10.1175/ JCLI-D-14-00521.1.

Opar, A., 2015: Lost at sea: Starving birds in a warming world. Audubon Magazine, March-April 2015, https://www.audubon. org/magazine/march-april-2015/lost-sea-starving-birds-warmingworld.

Reynolds, R. W., T. M. Smith, C. Liu, D. B. Chelton, K. S. Casey, and M. G. Schlax, 2007: Daily high-resolution-blended analyses for sea surface temperature. J. Climate, 20, 5473-5496, https:// doi.org/10.1175/2007JCLI1824.1.

Richman, M. B., 1986: Rotation of principal components. J. Climatol., 6, 293-335, https://doi.org/10.1002/joc.3370060305.

Rienecker, M. M., and Coauthors, 2008: The GEOS-5 data assimilation system-documentation of version 5.0.1 and 5.1.0, and 5.2.0. NASA Tech. Rep. Series on Global Modeling and Data Assimilation, NASA/TM-2008-104606, Vol. 27, 92 pp.

_, and Coauthors, 2011: MERRA: NASA's Modern-Era Retrospective Analysis for Research and Applications. J. Climate, 24, 3624-3648, https://doi.org/10.1175/JCLI-D-11-00015.1.

Ropelewski, C. F., and M. S. Halpert, 1986: North American precipitation and temperature patterns associated with the El Niño/Southern Oscillation (ENSO). Mon. Wea. Rev., 114, 2352-2362, https://doi.org/10.1175/1520-0493(1986)114<2352: NAPATP $>2.0 . \mathrm{CO} ; 2$.

Schubert, S. D., and Y.-K. Lim, 2013: Climate variability and weather extremes: Model simulated and historical data. 
Extremes in a Changing Climate: Detection, Analysis, and Uncertainty, A. AghaKouchak et al., Eds., Water Science and Technology Library Vol. 65, Springer, 239-285, https:// doi.org/10.1007/978-94-007-4479-0_9.

Seager, R., N. Harnik, Y. Kushnir, W. Robinson, and J. Miller, 2003: Mechanisms of hemispherically symmetric climate variability. J. Climate, 16, 2960-2978, https://doi.org/10.1175/ 1520-0442(2003)016<2960:MOHSCV>2.0.CO;2.

—_, Y. Kushnir, C. Herweijer, N. Naik, and J. Velez, 2005: Modeling of tropical forcing of persistent droughts and pluvials over western North America: 1856-2000. J. Climate, 18, 4065-4088, https://doi.org/10.1175/JCLI3522.1.

—, M. Hoerling, S. Schubert, H. Wang, B. Lyon, A. Kumar, J. Nakamura, and N. Henderson, 2015: Causes of the 2011-14 California drought. J. Climate, 28, 6997-7024, https://doi.org/ 10.1175/JCLI-D-14-00860.1.

Siler, N., Y. Kosaka, S.-P. Xie, and X. Li, 2017: Tropical ocean contributions to California's surprisingly dry El Niño of 2015/16. J. Climate, 30, 10067-10079, https://doi.org/10.1175/ JCLI-D-17-0177.1.

Simmons, A., J. M. Wallace, and G. Branstator, 1983: Barotropic wave propagation and instability, and atmospheric teleconnection patterns. J. Atmos. Sci., 40, 1363-1392, https://doi.org/10.1175/ 1520-0469(1983)040<1363:BWPAIA $>2.0 . C O ; 2$.

Straus, D. M., and J. Shukla, 2002: Does ENSO force the PNA? J. Climate, 15, 2340-2358, https://doi.org/10.1175/ 1520-0442(2002)015<2340:DEFTP $>2.0 . C O ; 2$.

Thompson, D. W. J., and J. M. Wallace, 1998: The Arctic Oscillation signature in the wintertime geopotential height and temperature fields. Geophys. Res. Lett., 25, 1297-1300, https:// doi.org/10.1029/98GL00950.

Tokioka, T., K. Yamazaki, A. Kitoh, and T. Ose, 1988: The equatorial 30-60 day oscillation and the Arakawa-Schubert penetrative cumulus parameterization. J. Meteor. Soc. Japan, 66 , 883-901, https://doi.org/10.2151/jmsj1965.66.6_883.

Trenberth, K. E., G. W. Branstator, D. Karoly, A. Kumar, N.-C. Lau, and C. Ropelewski, 1998: Progress during TOGA in understanding and modeling global teleconnections associated with tropical sea surface temperatures. J. Geophys. Res., 103, 14 291-14 324, https://doi.org/10.1029/97JC01444.

Whitney, F. A., 2015: Anomalous winter winds decreases 2014 transition zone productivity in the NE Pacific. Geophys. Res. Lett., 42, 428-431, https://doi.org/10.1002/2014GL062634.

Woodhouse, C. A., 2003: A 431-yr reconstruction of western Colorado snowpack from tree rings. J. Climate, 16, 1551-1561, https://doi.org/10.1175/1520-0442-16.10.1551.

Yeh, S.-W., J.-S. Kug, B. Dewitte, M.-H. Kwon, B. Kirtman, and F.-F. Jin, 2009: El Niño in a changing climate. Nature, 461, 511-514, https://doi.org/10.1038/nature08316.

Yu, B., 2007: The Pacific-North American pattern associated diabatic heating and its relationship to ENSO. Atmos. Sci. Lett., 8 , 107-112, https://doi.org/10.1002/asl.160.

Yu, J.-Y., and Y. Zou, 2013: The enhanced drying effect of CentralPacific El Niño on US winter. Environ. Res. Lett., 8, 014019, https://doi.org/10.1088/1748-9326/8/1/014019.

,--1, S.-T. Kim, and T. Lee, 2012: The changing impact of El Niño on US winter temperatures. Geophys. Res. Lett., 39, L15702, https://doi.org/10.1029/2012GL052483. 